\title{
Türk Hat Sanatında Hz. Muhammed Sevgisini Konu Alan Çalışmalar
}

\author{
Studies on The Love of The Prophet Muhammed in The Calligraphy of Turks
}

\section{Mehmet Memiş*}

\section{Öz}

İslâm sanat ve kültürü içinde müstesna bir yere sahip olan hat sanatı, tarihî gelişimini bilhassa Mushaf kitabeti üzerinde göstermiştir. Şüphesiz yazının bir sanat hâline gelmesinde İslâm’ın okumaya ve yazmaya verdiği önem yanında $\mathrm{Hz}$. Peygamber'in bu husustaki teşvikkâr tutumu da etkili olmuştur. Asırlar boyu devam eden gelişme ve arınma sürecinden sonra Osmanlı döneminde yetişen ünlü hattatlar eliyle tarihindeki en yüksek seviyesine ulaşmış olan hat sanatı, dünya ülkelerindeki çeşitli müzelerde yer bulan örnekleriyle evrensel bir boyut kazanmıştır. Başlı başına bir sanat dalı olmakla beraber, yerine göre başka sanat teknikleriyle de birleştirilebilen yazı, Türk İslâm sanatı içinde geniş bir kullanım alanına sahiptir. Bu makalede Hz. Muhammed sevgisi, onun örnek şahsiyeti, söz ve davranışları gibi konular etrafında ortaya konan hat eserleri ele alınmıştır. Bu tür hat eserlerinin başında yazma kitaplar ve bilhassa Mushaflar gelmektedir. Yazma kitaplar içinde Hz. Muhammed'in söz ve davranışlarını içeren hadis ve şemâil kitapları da önemli bir yer tutar. Makalede metinleri çoğunlukla hadîs-i şeriflerden oluşan kıt'alar, kıt'aların bir araya getirilmesi ile oluşturulan murakkaalar, Hz. Peygamber'le ilgili âyetlerin ve peygamber sevgisini işleyen edebî metinlerin yazıldığı levhalar, levhalar içinde Hz. Muhammed'in sözle tasviri mahiyetindeki hilye-i şerîfeler görsel örnekleri eşliğinde değerlendirilmiştir.

\section{Anahtar Kelimeler}

Hat sanatı, İslâm sanatı, Hattat, Hat eseri, Hz. Muhammed, Hz. Muhammed sevgisi

\begin{abstract}
Calligraphy, which has an exceptional place in Islamic art and culture, has shown its historical development especially on the Qur'an inscription. Undoubtedly, besides the importance that Islam attaches to reading and writing, the encouraging attitude of the Prophet on this issue has also been effective in making writing an art. Calligraphy reached its highest level in history through famous calligraphers. It became prominent in the Ottoman period after the development and purification process that continued for centuries, and gained a universal dimension with examples found in various museums around the world. As well as an art branch by itself, calligraphy, which is combined with other art techniques, accordingly, has wide usage in Turkish Islamic art. In this article, calligraphy works about topics such as love of the Prophet Muhammed, his exemplary personality, words, and behavior are discussed. Manuscripts and especially Qur'ans are at the top of this kind of calligraphy. Hadith and schamail books, which contain the words and behavior of the Prophet Muhammed, also have an important place among handwritten books. Kit'as which are mostly composed of hadiths, murakkas (albums) created by combining kıt'as, panels on which the verses about the Prophet and literary texts involving the love of the Prophet are written, hilyes in the form of verbal portrayal of the Prophet Muhammed were evaluated with visual examples.
\end{abstract}

\section{Keywords}

Calligraphy, Islamic Art, Calligrapher, Calligraphy Work, Prophet Muhammed, Love of the Prophet Muhammed

* Sorumlu Yazar: Mehmet Memiş (Doç. Dr.), Sakarya Üniversitesi, İlahiyat Fakültesi, İslam Tarihi ve Sanatları Bölümü, Sakarya, Türkiye. E-posta: mmemis@sakarya.edu.tr ORCID: 0000-0002-7962-3782

Atıf: Memis, Mehmet. "Türk Hat Sanatında Hz. Muhammed Sevgisini Konu Alan Çalışmalar." Art-Sanat, 14(2020): 241-272. https://doi.org/10.26650/artsanat.2020.14.0010 


\section{Extended Summary}

As an individual of the society in which they are grown, artists reflect the values, sensibilities, beliefs, love, and excitement of that society in their work. Undoubtedly, one of the primary values of Muslim societies is the Prophet of Islam, Muhammed. For this reason, the works on his life and love in the hearts have taken a great place in the art accumulation of Muslim Turks throughout history. From literary arts to ornamentation, from architecture to music, in the various branches of art, the precious works put forward on this subject are also one of the most effective means of transferring the love of the Prophet Muhammed to the next generation.

One of the arts where love of the Prophet is handled is calligraphy. With its widespread use in Ottoman language "hüsn-i hatt", calligraphy is described as the art of measured and beautiful writing in the Arabic alphabet in accordance with the aesthetic base formed in its historical process. Those who perform this art are called calligraphers. Islamic writing started to gain an aesthetic dimension with the encouragement and advice of the Prophet Muhammed. It can be said that writing began the process of becoming an art in that period as a result of the efforts to record the revelation. As a matter of fact, his advice to scribes regarding the manner of writing show that the Messenger of Allah also gave importance to the aesthetic aspect of writing. The hadith which means "Allah is beautiful and loves beauty" has been the guide of those who are looking for beauty in every subject. It was also known that the Prophet insisted on the importance of learning and teaching writing. The calligraphers, who took their inspiration from the Qur'an and recommendations of the Prophet, worked on writing with the excitement of worship and made it a branch of art unlike any other culture. This art, which completed its course of development, especially on the writing of the Qur'an, matured and diversified in the hands of Muslim artists who have devoted themselves and has taken its place as a beautiful element in every field where writing was used over time.

For centuries, calligraphers created numerous beautiful works on the exemplary personality and hadiths of the Prophet Muhammed, and especially on the Qur'an and verses. The majority of these works, which are the most beautiful examples of the expression of love of the Prophet through art, were handwritten books. The first thing that comes to mind when book is said in Islamic society is Mushaf, namely the Holy Qur'an. Islamic writing showed its historical development on writing of the Qur'an. Just as writing Mushaf is the aim of every calligrapher, Mushafs are the works of calligraphers that show the most care and skill. The Qur'an is the most important trust that the Messenger of Allah left to Muslims. Serving the Qur'an means gaining the sake of Allah and the pleasure of the Prophet.

Among handwritten books, hadith, schamail and dalail books related to the branches of science that deal with the Prophet and his words and behavior constitute an im- 
portant area. Although most of these books were written without regard to the artistic aspect, there were also books and magazines written by master calligraphers, which have artistic value with their illuminations and bindings. Forty hadith magazines were among works written by calligraphers with care due to rumors stating that those who know the forty hadiths by heart will be rewarded on doomsday.

A group of calligraphy works containing the hadiths of the Prophet Muhammed were also known by the names of kit'a and murakkaa. In an average book page size, the writings written in one or several fonts are called kit'a, and kit'a albums attached to each other and folded together are called murakkaa. As they were stored in cabinets and bookcases, these works were also bound carefully as books, and illumination or marbling were applied in their ornaments. Almost all Turkish calligraphers performed this kind of work. On the other hand, some literary texts written by the poets as praise to the Prophet were also included in the kit'a and murakkaa.

The panels, one of the most common calligraphy works, were works that adorned the walls, prepared for hanging somewhere and looking across. On these panels there were sometimes compliments written about the Prophet, verses expressing praise to him, mostly verses and hadiths containing brief and concise messages. Muslims decorated their living spaces with the wise words and advice of the Prophet Muhammed and showed their love and affection towards him.

Among these panels, Hilye-i Şerîfe had special importance in terms of expressing the love of the Prophet. Hilye, which means "ornament, adornment, jewel, beautiful characteristic, beautiful face" in the dictionary, is a concept that refers to poetic or prosaic literary work which expresses the blessed qualities and beauties of the Prophet Muhammed, and on panels written by calligraphers. Hilye, which was formed as a result of love and respect for the Prophet, became more widespread in Ottoman culture, gained great importance and reputation, and it was customary to ask a calligrapher to write a hilye and hang it on the wall, and some beliefs occurred around them due to the sacred meaning they carry. The first and most important example of the hilye form in Turkish literature is "Hilye" written by Hâkanî Mehmet Bey in 1007/1598-99. After this work, the word hilye became the general name of work created especially about the body structure and characteristics of the Prophet. The work, which started with a poem about Basmala, later mentioned narration of the Caliph Ali about the hilye and its virtues. In Istanbul libraries, there are many handwritten ones that involve couplets explaining the features of the Prophet's body structure.

Writing of hilye in panels and ornamenting it were unique to Ottoman Turks, and no such practice was observed in other Islamic countries. Although it was not explicitly included in references, it is accepted that the panel-shaped hilye was written for the first time by calligrapher Hâfiz Osman (d. 1110/1698). These works continue to 
be the center of attention of art lovers in our time as they were in the past, and very beautiful examples are produced by today's calligraphers both in their classical form and with their new and different trials. 


\section{Giriş}

Sanatçılar, içinde yetiştikleri toplumun bir bireyi olarak o toplumun değer yarg1larını, hassasiyetlerini, inanç, sevgi ve heyecanlarını yaptıkları eserlere yansıtmaya özen gösterirler. Şüphesiz Müslüman toplumların en başta gelen değerlerinden biri, Allah'ın dinini kendisinden öğrenip örnek aldıkları Hz. Muhammed (a.s.)'dir. Bu nedenle, onun yaşantısını ve gönüllerde yer eden sevgisini konu alan çalışmalar, tarih boyunca Müslüman Türklerin sanat birikimleri içinde büyük bir yekûn oluşturmuştur. Edebî sanatlardan süslemeye, mimarîden mûsikîye sanatın birçok dalında, bu mevzuda ortaya konan nadide eserler, aynı zamanda Hz. Muhammed sevgisini sonraki nesillere aktarmanın en etkili vasıtalarındandır.

Peygamber sevgisinin sanat boyutunda işlendiği alanlardan biri de hat sanatıdır. Osmanlı lisanındaki yaygın kullanımı ile (Arapça hüsn: "güzellik" ve hat: "yazı" kelimelerinden meydana gelen) hüsn-i hat: Tarihî süreci içerisinde oluşan estetik kâidelerine uygun olarak, Arap Elifbâsıyla icra edilen ölçülü ve güzel yazı yazma sanatı anlamına gelir. ${ }^{1}$ İslâm yazısı bizzat Resûlullâh'1n teşvik ve tavsiyeleri ile estetik boyut kazanmaya başlamıştır. İlk nazil olan "Oku!" ilâhî emri ile daha da önemli hâle gelen yazının, Hz. Peygamber devrinde vahyin yazıya geçirilmesi hususundaki gayretler sonucu sanat olma yoluna girdiği söylenebilir. Nitekim Resûlullah'ın yazı yazma âdâbı ile ilgili olarak kâtiplerine yaptığı tavsiyeler kaynaklara geçmiştir. "Hokkaya lika koy, kalemi eğri kes, Besmelenin 'Bâ'sını dik yaz, 'Sin'in dişlerini belli et, 'Mim'in gözünü açık yap, 'Nun'un çanağını uzat..."2 gibi ikazları onun yazının estetik yönüne de önem verdiğini gösterir. Hz. Peygamber bir taraftan bilginin yazıya geçirilerek muhafaza edilmesini emretmiş, diğer taraftan da çocuklara okuma yazma öğretmenin babalar için önemli bir vazife olduğunu dile getirmiştir. ${ }^{3}$

"Allah güzeldir, güzelliği sever"4 anlamındaki hadîs-i şerif de her konuda güzeli arayanların rehberi olmuştur. Kur'ân'dan ve Hz. Peygamber'in tavsiyelerinden ilham alan hattatlar, bir ibâdet heyecanıyla üzerinde çalıştıkları yazıyı müstesna bir sanat dalı hâline getirmişlerdir. Gelişme seyrini bilhassa Kur'ân-1 Kerîm kitâbeti üzerinde tamamlayan bu sanat, ona gönül veren Müslüman sanatkârların elinde olgunlaşıp çeşitlenerek, zamanla yazının kullanıldığı her alanda bir güzellik unsuru olarak yerini almıştır. Asırlardır farklı yazı biçimlerinin farklı tekniklerle uygulandığı hat eserleri içinde Hz. Muhammed'in örnek hayatı ve şahsiyeti etrafında verilen eserler önemli bir yer tutar. Peygamber sevgisinin sanat vasitası ile ifadesinin en güzel misalleri olan bu çalışmaları şu şekilde sınıflandırmak mümkündür:

1 Mehmet Memiş, "Hat Sanatına Terminolojik Bir Yaklaşım”, XX. Uluslararası Ortaçağ ve Türk Dönemi Kazıları ve Sanat Tarihi Araştırmaları Sempozyumu Bildirileri (Sakarya: Sakarya Üniversitesi Yayınları, 2017), 2: 554, 555.

2 Muhittin Serin, Hat Sanatı ve Meşhur Hattatlar (İstanbul: Kubbealtı Yayınları, 2010), 56-57.

3 Nihad M. Çetin, "İslâm Hat Sanatının Doğuşu ve Gelişimi”, İslâm Kültür Mirâsında Hat Sanatı (İstanbul: IRCICA, 1992), 15.

4 Müslim, "İman”, 147. 


\section{Yazma Kitaplar}

\section{a. Mushaflar}

İslâm toplumunda kitap denilince ilk akla gelen Mushaf'tır. Sözlükte "Bir araya toplanıp bağlanmış sayfalar"s anlamına gelen bu kelimeyle doğrudan Kur'ân-1 Kerîm anlaşılır. El yazması kitaplar içinde büyük bir yekûn oluşturan Mushaflar, İslâm yazısının bir sanat yazısı hâline gelmesinin başlıca sebebidir. Çünkü hat sanatı tarihî gelişimini Kur'ân-1 Kerîm kitâbeti üzerinde sergilemiştir. Her hattatın hedefinde Mushaf yazmak olduğu gibi, hattatların en fazla özen ve hüner gösterdikleri eserleri de Mushaflardır. Çünkü o, Resûlullah'ın ümmetine bıraktığı en önemli emânetidir. Ona hizmet etmek demek, Allah'ın rızasını ve Peygamberinin hoşnutluğunu kazanmak demektir. Ayrıca hattatlar, bu kutsal emâneti sonraki nesillere eksiksiz ve hatasız bir şekilde ulaştırmak gibi ağır bir sorumluluk yüklenmişler ve bu görevi lâyıkıyla yerine getirmek için canla başla gayret etmişlerdir.

Bilindiği üzere Hz. Peygamber (a.s.) Kur'ân âyetlerini bir taraftan ezberleterek, bir taraftan da görevlendirdiği vahiy kâtiplerine yazdırarak sağlığında kayıt altına alınmasını sağlamıştı. Bir âyet nazil olduğunda, kâtiplerinden birini çağırıp ona yazdırır, yazılanları tekrar okutarak doğruluğunu kontrol eder, eksik veya yanlış varsa hemen düzeltilmesini sağlardı. Böylece muhafaza altına alınan vahyin iki kapak arasında toplanarak Mushaf hâline getirilmesi ise Hz. Ömer'in teklifi üzerine ilk Halife Hz. Ebû Bekir zamanında gerçekleştirildi. Bilâhare yeni fetihler sırasında Şam ve Iraklı askerlerin Kur'ân okuyuşlarındaki farklılıklar yüzünden ihtilaflar ortaya çıktı. Bu durumun bir fitneye yol açabileceği endişesiyle Hz. Osman, Hz. Ebû Bekir zamanında yazılan ve Resûl-i Ekrem'in eşi Hz. Hafsa'da bulunan Mushaf'ı esas alarak, ilk Mushaf'ın hazırlanmasında görevli olan Zeyd b. Sâbit'in de aralarında bulunduğu istinsah heyetine yeni nüshalar yazdırdı. ${ }^{6}$ Bu Mushaflar Mekke, Kûfe, Basra, Şam, Medîne gibi önemli merkezlere birer rehber kâri ile gönderilerek, bunların dışındaki özel nüshaların imhâ edilmesi istendi. Böylece kıraat farklılıkları nedeniyle Müslümanlar arasında meydana gelebilecek anlaşmazlıkların önüne geçilmiş oldu. İstinsah heyeti tarafından belirlenen imlâ kuralları esas alınarak çoğaltılan bu Mushaflar ${ }^{7}$ işlenmiş deriden sayfalar (parşömen) üzerine siyaha yakın koyu kahverengi mürekkeple yazıldı. İmlâda, daha sonra Kûfi adıyla anılacak olan Medenî yazı şekli kullanıldı. Kur'ân metninden olmayan herhangi bir işaret ilâve edilmedi. "Mushaf kitâbeti için seçilmiş olan bu yazı düzenli, geometrik, ritmik, yatay ve dikey çizgilerin hâkim olduğu noktasız, harekesiz bir yazı türü idi”.

5 Abdülkadir Yılmaz, Türk Kitap Sanatları Tabir ve Istılahları (İstanbul: Damla Yayınevi, 2004), 237.

6 Tayyar Altıkulaç, Hz. Osman'a Nisbet edilen Mushaf-ı Şerîf (İstanbul: TDV İslam Araştırmaları Merkezi, 2007), $1: 19,31$.

7 Hz. Osman Zamanında Zeyd b. Sâbit bașkanlığında kurulan Mushaf İstinsah Heyeti, Mushafların imlâsında uyulması gereken bazı kaideler koydular. Bu usullere Hatt-1 Osmânî, Resm-i Osmânî veya Resm-i Mushaf denir. Bkz. Serin, Hat sanatı ve Meşhur Hattatlar, 53; Yılmaz, Türk Kitap Sanatları Tabir ve Istılahları, 118.

8 Serin, Hat Sanatı ve Meşhur Hattatlar, 58-59. 
Hz Osman zamanında yazılan Mushafların sayısı hakkında kaynaklarda dört ile sekiz arasında farklı sayılar ileri sürülmüştür. Bu bilgiler değerlendirildiğinde en az altı adet olduğu söylenebilir. Bu Mushafların geçmişte nerelerde bulunduğuna dâir bazı bilgiler mevcut olsa da, bu bilgileri doğrulama imkânı bulunmamaktadır. Bugün bazı müze ve kütüphanelerde Hz. Osman Mushaflarından olduğu ileri sürülen nüshalar mevcuttur. Ancak bu nüshalar üzerinde metin çalışmasına dayalı detaylı incelemeler yapmış olan Dr. Tayyar Altıkulaç, bunların Hz. Osman Mushaflarından yahut da onlar esas alınarak yazılmış ikincil nüshalardan çoğaltılan Mushaflar olduğu kanaatini dile getirmektedir. ${ }^{9}$

Emevîler döneminde Mushaf yazan kâtiplerin sayıları çoğaldığı gibi tecrübeleri de arttı. Buna bağlı olarak satır düzeninde, harflerin, kelimelerin oran ve biçimlerinde gelişmeler oldu. Diğer taraftan, Kur’ân kırâatinde görülen yanlışlıkları gidermek, rahat ve doğru okunabilmesini sağlamak amacıyla harekeleme ve noktalama çalışmaları başladı. Ebü'I-Esved ed-Düelî kırmızı renkli yuvarlak noktalar ile, Nasr b. Asım ve Yahya b. Ya'mer, eğik çizgi şeklinde harekeleme çalışmaları yaptılar. Halil b. Ahmed'in usulü ile de hareke ve mühmel işaretleri bugünkü şeklini almıştır. ${ }^{10}$ Yurt dışındaki müze ve kütüphanelerde muhafaza edilen örneklerden başka, İstanbul'daki Türk ve İslam Eserleri Müzesi, Topkapı Sarayı Müzesi ve Süleymaniye Kütüphanesi koleksiyonlarında Mushaf kitâbetinde görülen bu gelişmeleri sergileyen nâdîde Kur'ân-1 Kerîm'ler ve çeşitli formlarda Kur'ân'dan metinler mevcuttur. ${ }^{11}$

Abbâsîler döneminde yetişen kâtipler yumuşak, kavisli hatların hâkim olduğu mevzun hatlarda önemli yenilikler yaptı. Hat sanatının ünlü isimlerinden İbni Mukle ve kardeşi Ebu Abdullah Hasan b. Ali, harflerin ölçü ve kurallarını belirleyerek Aklâm-l Sitte denilen yazı çeşitlerinin ortaya çıkışına zemin hazırlamıştır. Bu devirde çalışan verrâkların (müstensih, kâtip) Mushaf ve kitap istinsahında geliştirdikleri "Neshî" yazı daha sonra Reyhânî ve Nesih adlarıyla ikiye ayrılarak devam etmiştir. Abbâsî döneminin ikinci büyük hat üstadı İbni Bevvâb (ö. 413/1022), İbni Mukle’nin Aklâm-1 Sitte'de ortaya koyduğu kuralları daha da geliştirerek güzelleştirdi. İbni Bevvâb'ın altmış dört Mushaf yazdığg bilinmektedir. Aklâm-1 Sitte'nin klâsik kurallarını belirleyen Yakut el-Musta'sımî (ö. 698/1298), Mushaf kitâbetinde yeni bir çığır açtı. Muhakkak, Reyhanî, Sülüs ve Nesih hatlarıyla Mushaf yazımına zenginlik kazandırdı. ${ }^{12}$

9 Altıkulaç, Hz. Osman'a Nisbet edilen Mushaf-ı Şerîf, 33, 34.

10 Muhittin Serin, "Mushaf", TDV İslâm Ansiklopedisi, c. 31 (İstanbul: Türkiye Diyanet Vakfı Yayınları, 2006), 249.

11 Dünyanın sayılı koleksiyonları arasında yer alan Türk ve İslam Eserleri Müzesi Kur’ân Koleksiyonundaki Mushaf ve Mushaf sayfalarından seçilen bir grup eser 2010 yılı Ramazan ayında, müzede düzenlenen " 1400. Yılında Kurân-1 Kerîm Sergisi” kapsamında üç ay süreyle ziyarete açıldı. 7. asır sonlarından 20. asır başlarına kadar İslam coğrafyasının farklı bölgelerinde yazılıp bezenmiş olan çeşitli form ve boyutlardaki bu nadide eserler için bir de katalog hazırlandı. Bkz. 1400. Yılında Kur'ân-ı Kerîm (İstanbul: Antik A.Ş. Kültür Yayınlar1, 2010), 143-455.

12 Çetin, İslâm Kültür Mirasında Hat Sanatı, 23-27; Serin, "Mushaf”, 250, 251. 


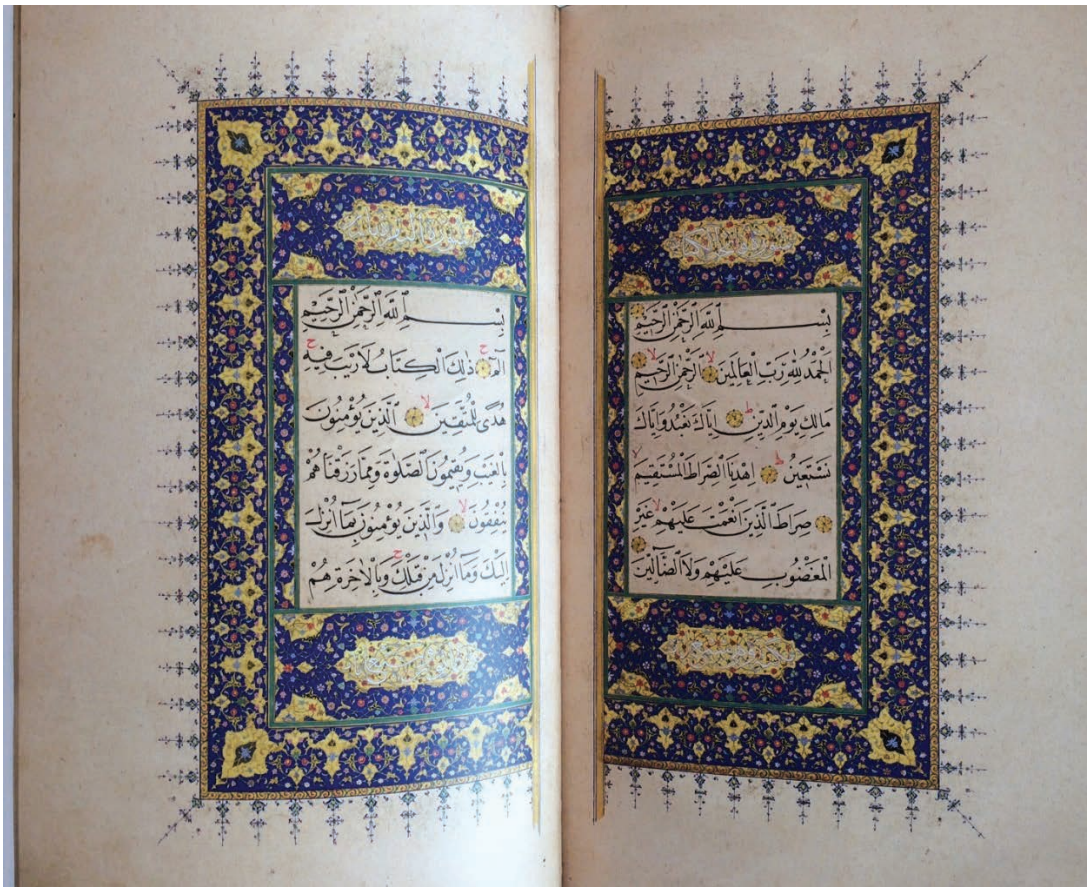

G. 1. Şeyh Hamdullah'a ait 914/1508 tarihli Mushaf'ın serlevhası

(Derman, Doksandokuz İstanbul Mushafi, 30, 31)

Hat sanatı XV. yüzyılda Amasyalı Şeyh Hamdullah (ö. 926/1520) ile İstanbul'da yeni bir üslup kazandı. Mushaf kitâbetinde okunması daha kolay olan Nesih yazı tercih edilerek sayfa ve satır düzeni en uygun ölçülere getirildi. ${ }^{13}$ (G. 1). Daha önce Mushaflar tek başına Kûfî, Muhakkak, Reyhânî, Sülüs veya Nesih'le yazıldığı gibi; bu yazı türlerinin ikili ya da üçlü grupları da Mushaf kitâbetinde bir arada kullanılıyordu. Ancak bu alanda Osmanlı zevkine en uygun düşen yazı türü Nesih oldu. ${ }^{14}$

Şeyh Hamdullah yolunda eserler veren Hâfız Osman (1642-1698) Nesih yazıya yeni güzellikler kazandırmıştır. Bilâhare basılan Mushaflarıyla İslâm dünyasında şöhret bulan Hafız Osman'dan sonra Yedikuleli Seyyid Abdullah (1670-1731), Şekerzâde Seyyid Mehmed (ö: 1166/1753), Eğrikapılı Mehmed Rasim (16881756) ve Kazasker Mustafa İzzet Efendi (1801-1876) Osmanlı hattatları arasında yazdıkları güzel Mushaflarla tanınmış olanlardır. Kayışzâde Hâfız Osman Nuri (ö. 1311/1894) tarafından yazılmış olan âyet-berkenar Mushaf ${ }^{15}$ tertibi Müslüman halk tarafından daha fazla ilgi görmüş, günümüze kadar pek çok baskısı yapılarak

13 Serin, "Mushaf”, 251.

14 M. Şinasi Acar, Türk Hat Sanatı (İstanbul: Antik A.Ş., 1999), 106.

15 Her sayfası tam bir âyetle bitip diğer sayfası başka bir âyetle başlayan mushaflar için "âyet-berkenar mushaf" tabiri kullanılır. Hâfızlık yapanların tercihinden dolayı bu mushaflara "mushaf-ı huffâz" da denir. Bkz. Yılmaz, Türk Kitap Sanatları Tabir ve Istılahları, 21. 
yaygınlaşmıştır. Hasan Rıza Efendi 1849-11920) de aynı tarzda yazdığ1 Mushaflarının açık, okunaklı, okutma işaretlerinin yerli yerince konulmuş olması ile bilinmektedir. ${ }^{16}$

\section{b. Diğer Kitaplar}

Hattatlar Mushaflardan sonra en çok Hz. Muhammed (a.s.)'in hayat1, şahsiyeti ve hadisleri etrafında güzel eserler vermişlerdir. Bu tür eserlerin başında, Hz. Peygamberi konu alan ilim dallarıyla ilgili hadis, şemâil ve delâil kitapları gelmektedir. Bilindiği gibi Hz. Peygamber'in söz, fiil ve takrirlerine ait haberlere hadîs denilmiştir. Bu haberler ashâb, tâbiûn ve etbâu't-tâbiîn denen ilk üç neslin verdiği bilgilere dayanmaktadır. Şemâil ve delâil bir bütünün iki ayrı yönünü andırmaktadır. Şemâil Hz. Peygamber'in beşerî yönünü ele alırken delâil de nebevî yönünü konu edinmiştir. Huy, tabiat, karakter, hâl, hareket gibi manalara gelen "şemâil" kelimesi daha özel anlamıyla; Hz. Peygamber (a.s.)'ın beşerî yönünü, yaşam biçimini ve kişisel hayatını anlatan bir terim hâlini almıştır. Alâmet, işaret, iz, delil, belge, kılavuz gibi anlamları olan "delâil" ise, onun sıradan insanlarda bulunmayan bir takım özelliklerini konu edinen eserleri ifade eder. ${ }^{17}$ Delâilü'n-nübüvve, Peygamberlik müessesesini, bilhassa Hz. Muhammed'in peygamberliğini ispatlamak için hazırlanan eserlerin ortak adıdır. ${ }^{18}$

Bu tür kitapların çoğu sanat yönü dikkate alınmadan yazılmış olmakla beraber, ünlü hattatlar tarafından yazılan, süslemeleri ve ciltleri bakımından da sanat kıymetine hâiz eserler önemli bir yekun oluşturmaktadır. Hattat Şeyh Hamdullah'ın Nesih hattıyla 901/1495-1496 tarihinde tamamladığı El-Begavî’nin (ö. 516/1122) Mesâbihu's-Sünne adlı eseri ${ }^{19}$ buna güzel bir örnek teşkil etmektedir (G. 2). Kütüb-i Sitte'den seçme hadisleri ihtiva eden bu eser 471 varak olup serlevha ve hâtime sayfaları tezhiblidir. ${ }^{20}$ Sultan V. Mehmed Reşad'ın Topkapı Sarayı Hırka-i Saadet Dairesi'nde okunması için vakfettiği Hattat Hasan Rıza Efendi tarafından Nesih hattıyla yazılmış sekiz ciltlik Sahîh-i Buhâri (el-Câmi'u s-Sahîh) hattı, tezhibi ve cildiyle mükemmel bir eserdir. ${ }^{21}$

16 Serin, "Mushaf", 251, 252.

17 Ali Yardım, Peygamberimizin Şemâili (İstanbul: Damla Yayınevi, 1997), 19-30.

18 Yusuf Şevki Yavuz, "Delâilü’n-Nübüvve”, TDV İslâm Ansiklopedisi, c. 9 (İstanbul: Türkiye Diyanet Vakfi Yayınlar1, 1994), 115.

19 TSMK, III. Ahmed, nr. 278.

20 Muhittin Serin, Şeyh Hamdullah (İstanbul: Kubbealtı Yayınları, 1992), 89.

21 Buhârî-i Şerîf, İstanbul, Topkapı Sarayı Müzesi Kütüphanesi, Hırka-i Saâdet, 39. 

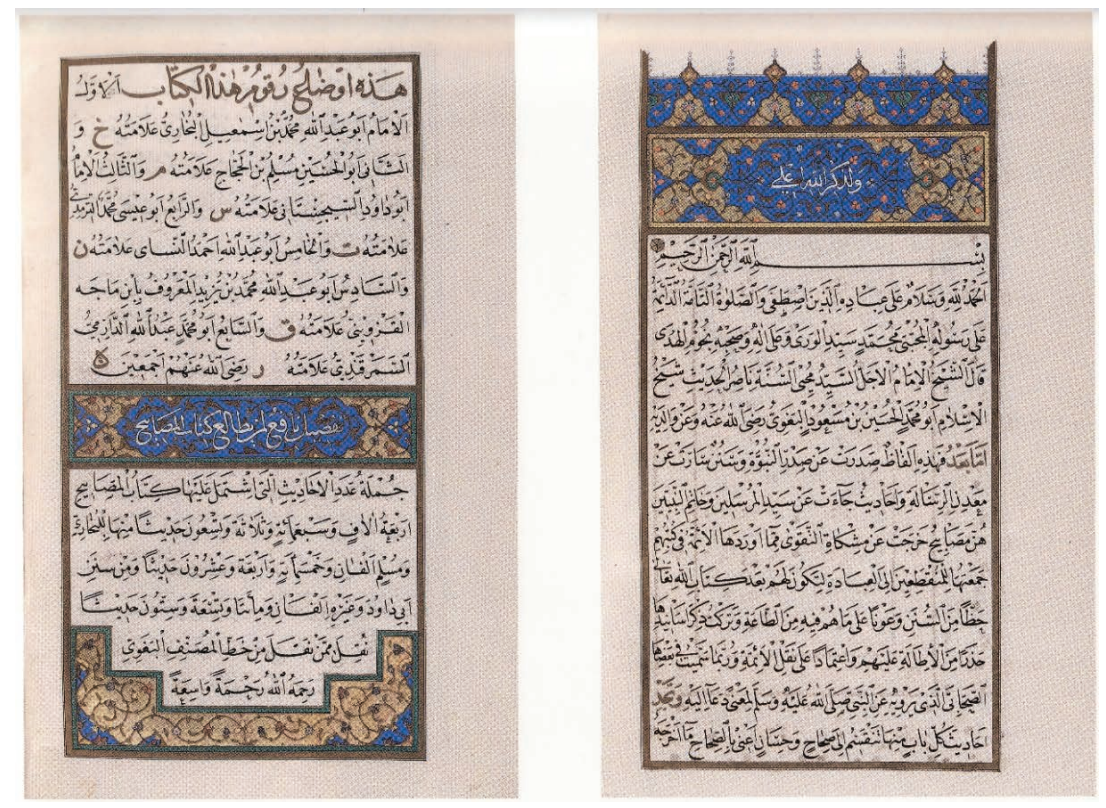

G. 2. Şeyh Hamdullah'ın yazdığı El-Begavî'nin Mesâbîhu 's-Sünne adlı eserinden, (Serin, Şeyh Hamdullah, 181)

1067 varaktan oluşan bu eserin Sahîh-i Buhâri'nin en sanatlı nüshası olduğu söylenebilir (G. 3). ${ }^{22}$ Ketebe kayıtlarından Sultan II. Abdülhamid Han döneminde yazımına başlanılıp, Sultan Mehmed Reşad döneminde, evâsıt-1 Rebîu'l-Âhir 1331/Mart 1913 tarihinde tamamlandığ 1 anlaşılan eser hâlen Topkapı Sarayı Müzesi Kütüphanesi'nde (Hırka-i Saâdet, No. 39) bulunmaktadır. Son üç cildin hâtime sayfaları müzehhib Ali Nazmî'nin imzasını taşır. ${ }^{23}$ Ünlü hattatlarımızdan Muhsinzâde Abdullah'ın II. Abdülhamid'in isteği üzerine yazdığı Şifâ-i Şerif de Nesih hattının en güzel örneklerindendir. Kânûni Sultan Süleyman için yazılan, Muslihıddîn-i Lârî’nin Şerh-i Şemâil-i Tirmizî ${ }^{24}$ adlı eseri klâsik cildi ve tezhibli serlevhasıyla çok değerli eserlerden biridir. ${ }^{25}$ Şeyh Muhammed b. Süleyman el-Cezûlî (ö. 870/1465) tarafindan derlenen ve Delâil, Delâil-i Şerîf, Delâil-i Hayrât adlarıyla anılan risâlenin çok sayıda istinsâhı yapılmıştır. Şâzeliyye tarikatının Cezûliyye kolunun kurucusu olan Şeyh Cezûlî’nin bu risâlesi, kendi müridleri, diğer tarikat mensupları ve hatta bir tarikata intisâbı bulunmayan Müslümanlar tarafindan faziletine inanılarak, belirli düzenler içinde okunan metinlerdendir (G. 4). ${ }^{26}$

22 M. Uğur Derman, İslâm Kültür Mirasında Hat Sanatı (İstanbul: IRCICA, 1992), 220, 221.

23 Elif İlter, "Hattat Hasan Rıza Efendi'nin Hayatı ve Eserleri” (Yüksek Lisans Tezi, Sakarya Üniversitesi, 2017), 129; Arafat Aydın, "Hattat Hasan Rizâ Efendi’nin Buhârî-i Şerîf Nüshası," Hattat Hasan Rızâ Hattı Buhârî-i Şerîf (İstanbul: Diyanet İşleri Başkanlığı Yayınları, 2017), xxxıv.

24 TSMK, III. Ahmed, nr. 4581.

25 Muhittin Serin, "Muhammed," TDV İslâm Ansiklopedisi, c. 30 (İstanbul: Türkiye Diyanet Vakfı Yayınları, 2005), 462 .

26 Süleyman Uludağ, "Delâilü'l-hayrât", TDV İslâm Ansiklopedisi, c. 9, (İstanbul: Türkiye Diyanet Vakfi Ya- 


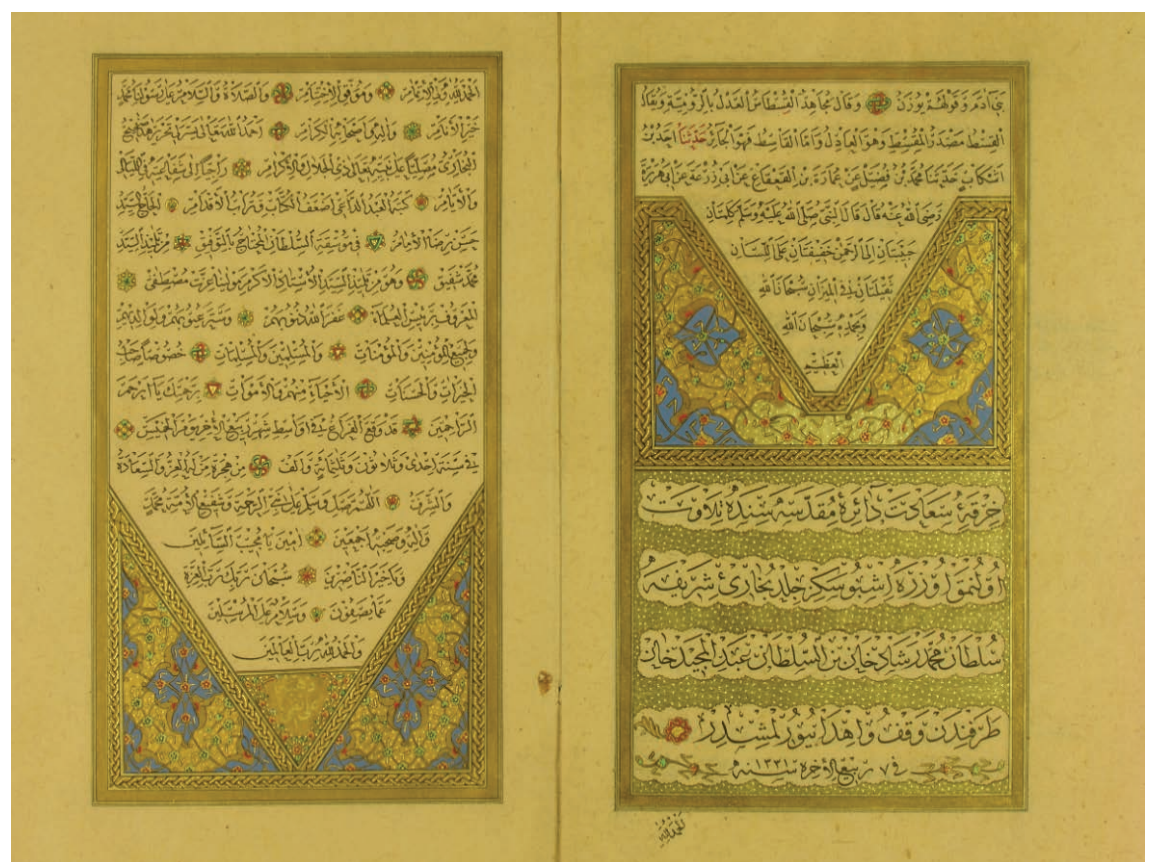

G. 3. Hasan Rıza Efendi tarafından yazılan Sahîh-i Buhâri'nin sekizinci cildi sonundaki vakıf ve feră̆ kayıtları (İstanbul, Topkapı Sarayı Müzesi Kütüphanesi, HS 39-8, 114b-115a)

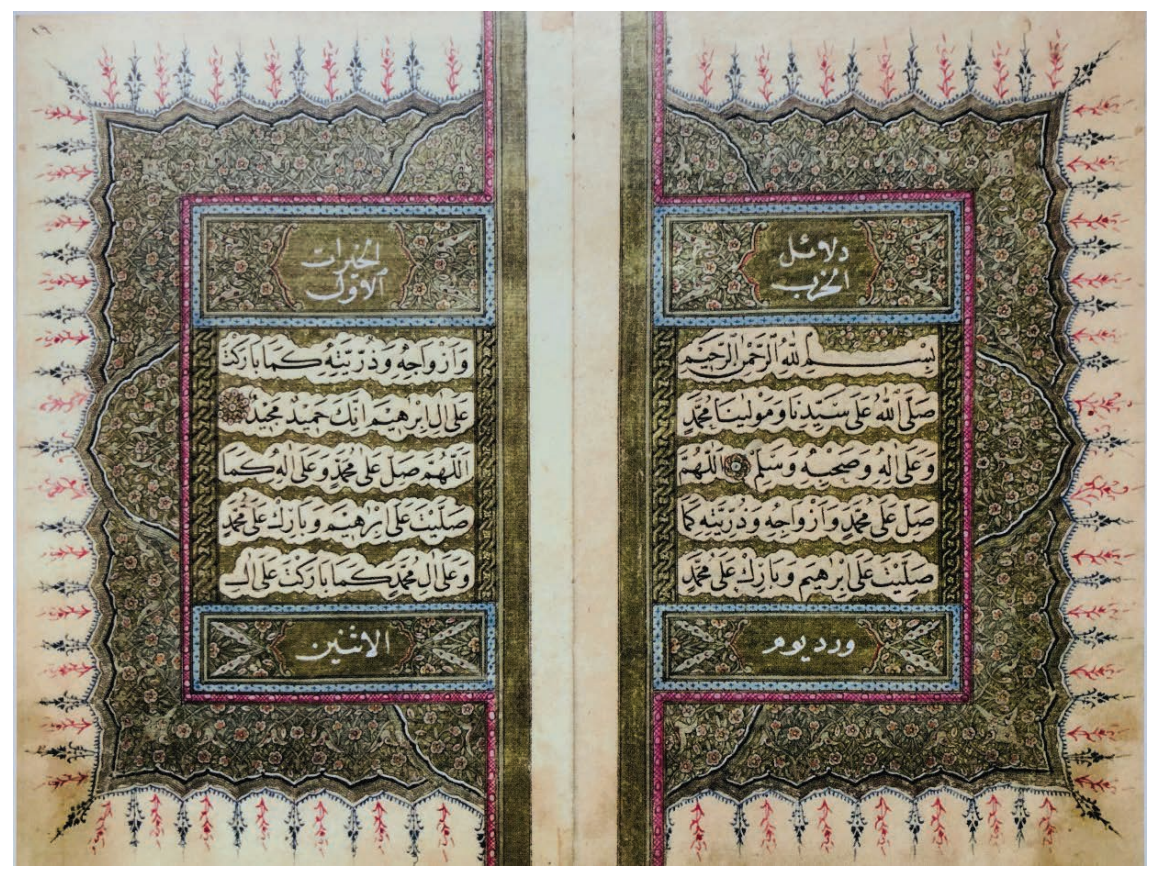

G. 4. Esma İbret'in Delâil-i Hayrât'ından, (Kazan, Dünden Bugüne Hanım Hattatlar, 49)

yınlar1, 1994), 113, 114. 


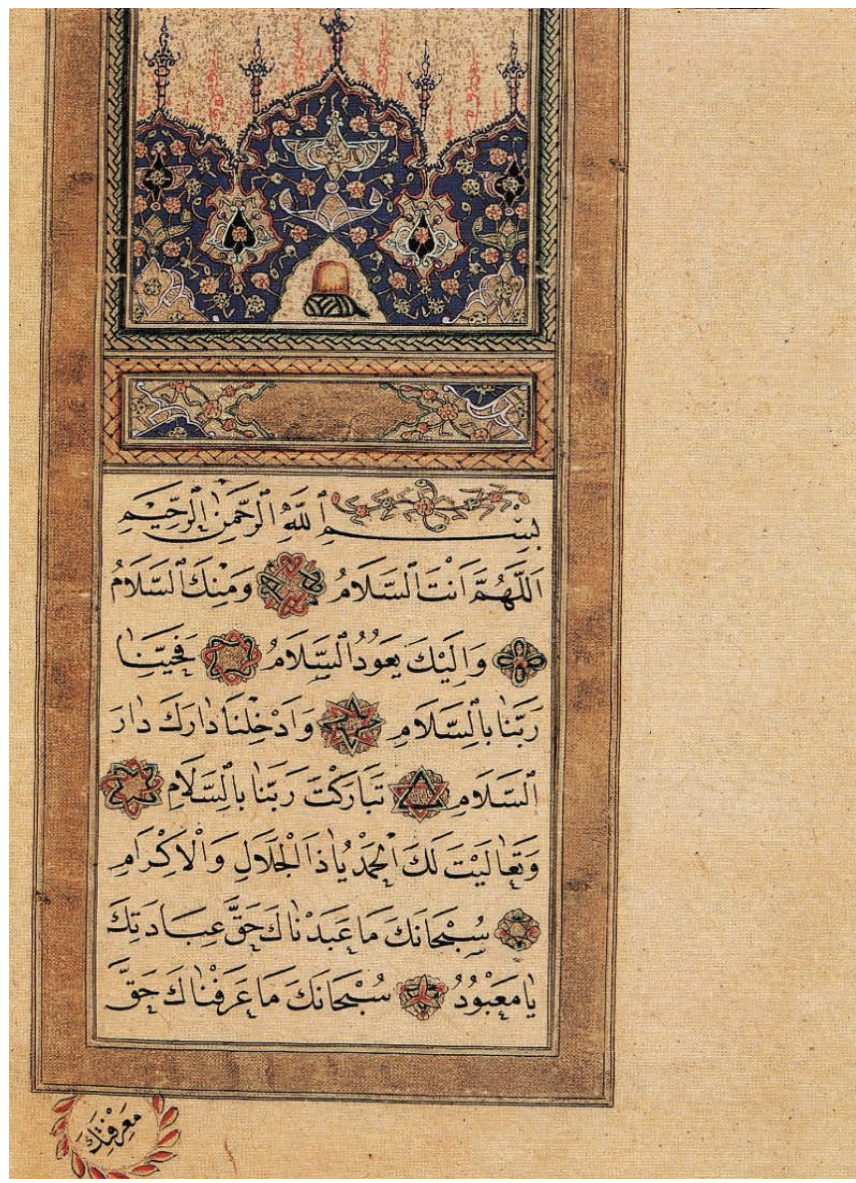

G. 5. Hacı Nuri Korman'ın Nesih hattıyla Mevlevî Evrâd-ı Şerîfesi (Serin, Hat Sanatı ve Meşhur Hattatlar, 186)

Kırk hadîs-i şerîfi ezbere bilenlerin büyük mükâfat göreceğine dâir rivâyetler sebebiyle yazılan kırk hadis mecmuaları hattatların ilgi ve özen gösterdikleri eserlerdendir. Hz. Peygamber için okunan çeşitli salavât ve duâları içeren evrâd ve duâ risaleleri de yazma kitaplar arasında önemli yer tutar. Müze ve kütüphanelerimizde bu tür çalışmaların kitap sanatları bakımından çok kıymetli örnekleri bulunmaktadır. Karahisârî’nin talebesi Hasan Çelebi tarafından Aklâm-1 Sitte ile yazılmış olan 974/1566 tarihli Evradu'l-üsbuıyye (yedi günlük dualar) adlı dua mecmuası, saray nakkaşhanesinin usta müzehhibleri tarafindan tezhiblenerek tahta çıktıktan sonra Sultan II. Selim'e sunulan önemli bir eserdir ${ }^{27}$. Hacı Nuri Korman'ın Nesih hattıyla yazdığ 1 Mevlevî Evrâd-l Şerîfesi ${ }^{28}$ de bu tür çalışmaların güzel örneklerindendir (G. 5). 


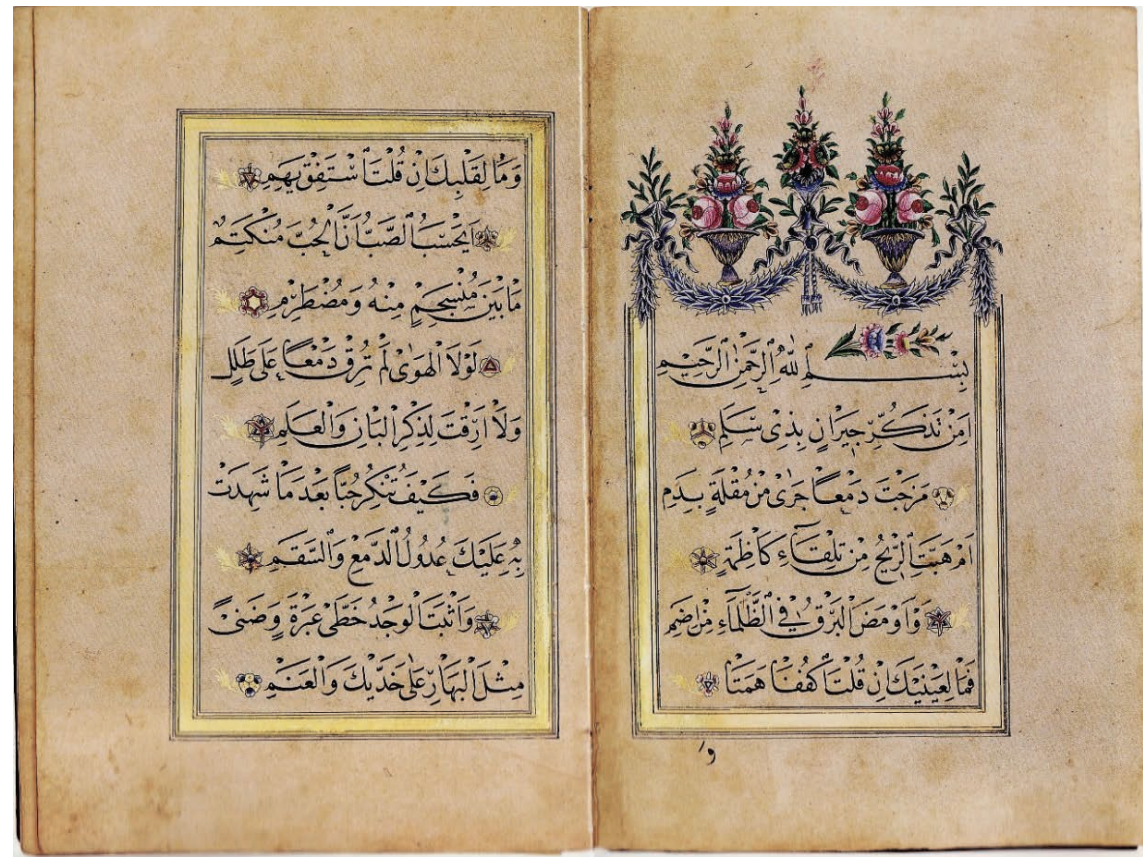

G. 6. Mehmet Şefik Bey'in Nesih Hattıyla Yazdığı Kasîde-i Bürde (Derman, S. Sabancı Müzesi Hat Koleksiyonundan Seçmeler, 174)

Şairlerin Hz. Peygambere övgü olarak yazdıkları bazı edebî metinler de hattatların ilgi odağı olmuştur. İslâmiyet'i henüz kabul etmiş olan Ka'b bin Züheyr İslâm Peygamberi'ne karşı bizzat bir şiir okumuş, bundan hoşnut olan Hz. Peygamber'de hırkasını çıkarıp Ka'b bin Züheyr'e giydirmiştir. Bundan dolayı Kasidetü'l-Bürde (hırka kasidesi) adıyla bilinen bu metin, kitap ya da murakkaa şeklinde birçok defa yazılmıştır. Mehmet Şefık Bey'in Nesih hattıyla yazdı̆̆ 10 varaklı Kasidetü'l-Bürde 1263/1847 tarihlidir ${ }^{29}$ (G. 6). Hâkanî Mehmet Bey'in 1007/1598-1599 tarihinde yazdığı Hilye adlı eseri de hilye türünün Türk edebiyatındaki ilk ve en önemli örneğidir. İstanbul kütüphanelerinde pek çok yazma nüshası bulunan eserde Hz. Peygamber'in vücut yapısı ile ilgili özelliklerini anlatan beyitler de yer almıştır ${ }^{30}$. Hilye-i Hakan̂े manzûmesinin beyitleri, Osmanlı Ta'lik hattatlarının mürekkebât meşki olarak yazdıkları metinlerin başında gelir (G. 7).

29 M. Uğur Derman, Sakıp Sabancı Müzesi Hat Koleksiyonundan Seçmeler (İstanbul: Akbank Yayınları, 2002), 174.

30 Mustafa Uzun, "Hâkâni Mehmed Bey," TDV İslâm Ansiklopedisi, c. 15 (İstanbul: Türkiye Diyanet Vakfi Yayınları, 1997), 167. 


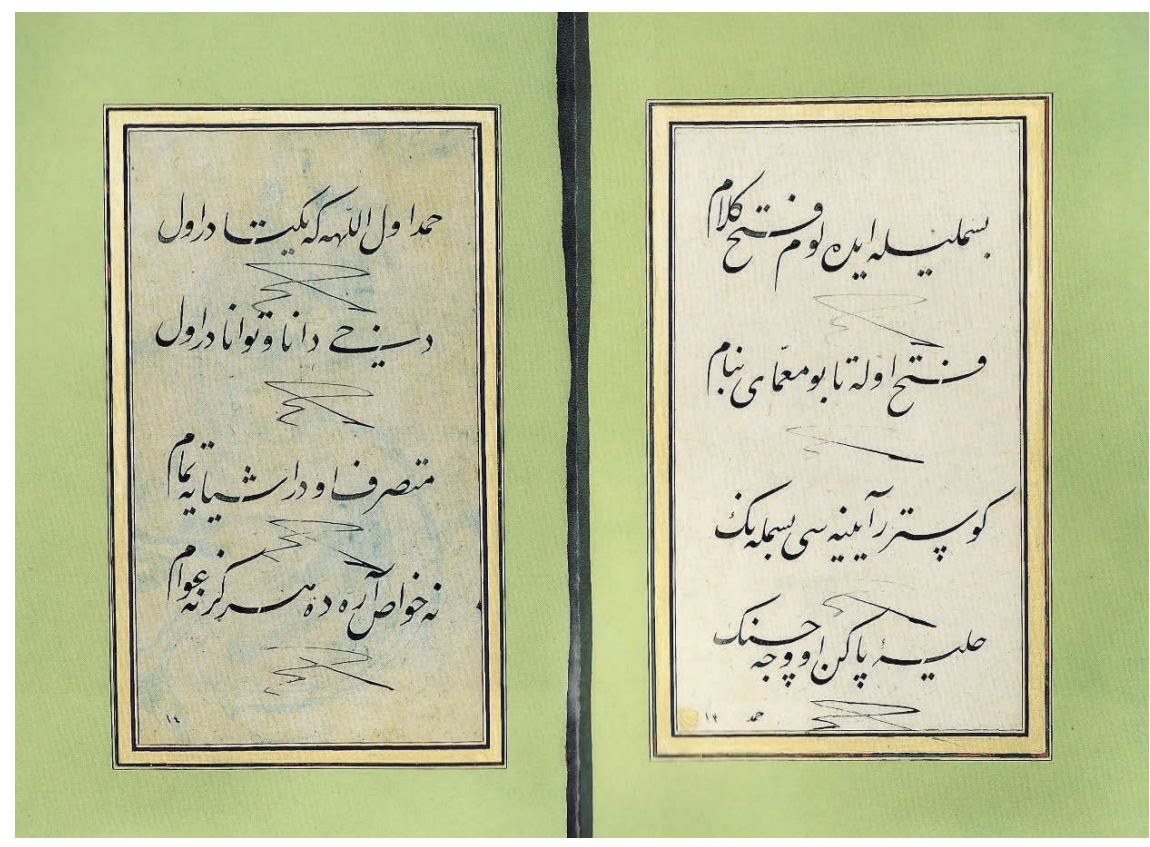

G. 7. Mehmed Sâdullah Efendi'nin Ta'lik hattılla Hilye-i Hâkânî beyitleri (Derman, Sakıp Sabancı Müzesi Hat Koleksiyonundan Seçmeler, 148)

\section{Kit'alar ve Murakkaalar}

Yaklaşık olarak bir kitap yaprağı boyutunda, bir ya da birkaç yazı çeşidi ile yazılan yazılara kit'a, kit'aların kenarlarından birbirine tutturulup bir araya toplanması ile meydana getirilen katlanabilir kıt'a albümlerine de murakkaa denilmektedir ${ }^{31}$. Kıt'alarda çoğunlukla Sülüs-Nesih, Muhakkak-Reyhâni, Tevki'-Rikâa' yazıları ikili olarak yer alır. Tek yazı türüyle yazılanlar ise daha çok Ta'lik kıt'alardır. Yazımında kullanılan hat cinsine gör isim aldığından Sülüs'le yazılmış olana "Sülüs kıt'a", SülüsNesih bir arada kullanılarak yazılana "Sülüs-Nesih kıt'a", Ta'likle yazılmış olana da "Ta' lik kıt'a" adı verilir. Dolap ve kitaplıklarda saklandıkları için kıt'alar da kitaplarda olduğu gibi özenle ciltlenmiş, süslemelerinde de tezhib veya ebru uygulanmıştır.

Birbirinin devamı şeklinde yazılmış murakkaa kıt'alarında her bir yazı türünün metni ayrı olarak devam eder. "Müteselsil murakkaa" denilen bu tarzda kıt'aların ibâreleri yarıda kalmışsa daha sonra gelenlerde tamamlanır. Müstakil kıt'aların bir araya getirilmesiyle sonradan hazırlanmış olanlara "Toplama Murakkaa" denilir. Bu tür murakkaalarda aynı hattata ait her biri ayrıca imzalanmış kıt'alar bulunabileceği gibi, farklı hattatlar tarafından yazılmış kıt'alar da bir araya getirilmiş olabilir. ${ }^{32}$

31 Acar, Türk Hat Sanatı, 119; Y1lmaz, Türk Kitap Sanatları Tabir ve Istılahlarl, 183, 235.

32 M. Uğur Derman, "Murakka”, TDV İslâm Ansiklopedisi, c. 31 (İstanbul: Türkiye Diyanet Vakfı Yayınları, 2006), 205. 


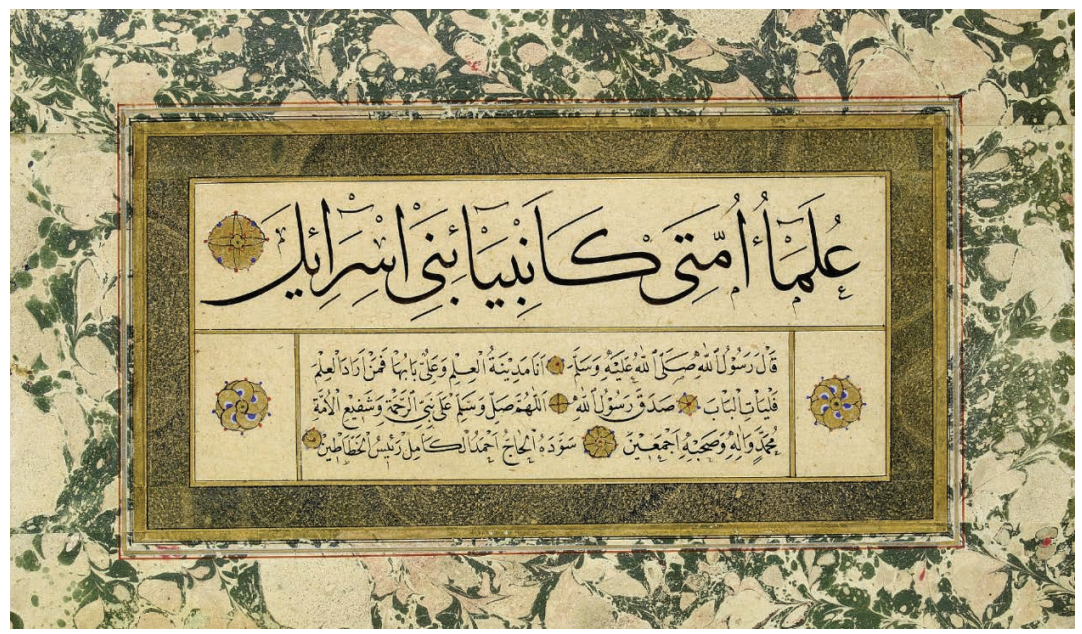

G. 8. Ahmed Kâmil Efendi'ye Ait Sülüs-Nesih Kıt'a,

(SSM Dijital Koleksiyonları ve Arşivleri, "Kitap Sanatları ve Hat Koleksiyonu,” nr. 110-0130)

Kit'alarda en fazla yazılan metinler, Hz. Muhammed (a.s.)'in hadisleridir. Mütevazı boyutlardaki bu eserlerde en meşhur hattatların en nefis yazılarını, en usta müzehhiblerin en güzel tezhiblerini görmek mümkündür. Bu alanda hattat Şeyh Hamdullah'1n Aklâm-1 Sitte (altı yazı çeşidi) ile yazdı̆̆ı kıt'a ve murakkaaları daha sonraki hattatlara örnek teşkil etmiş, hemen bütün Türk hattatları bu tarz eserler vermiştir (G. 8). Hz. Peygamber'e övgü olarak kaleme alınmış kasîdelerin ve onu anlatan hilye metinlerinin de kıt'a ve murakkaalarda özenle yazıldı̆̆ı görülür (G. 9).

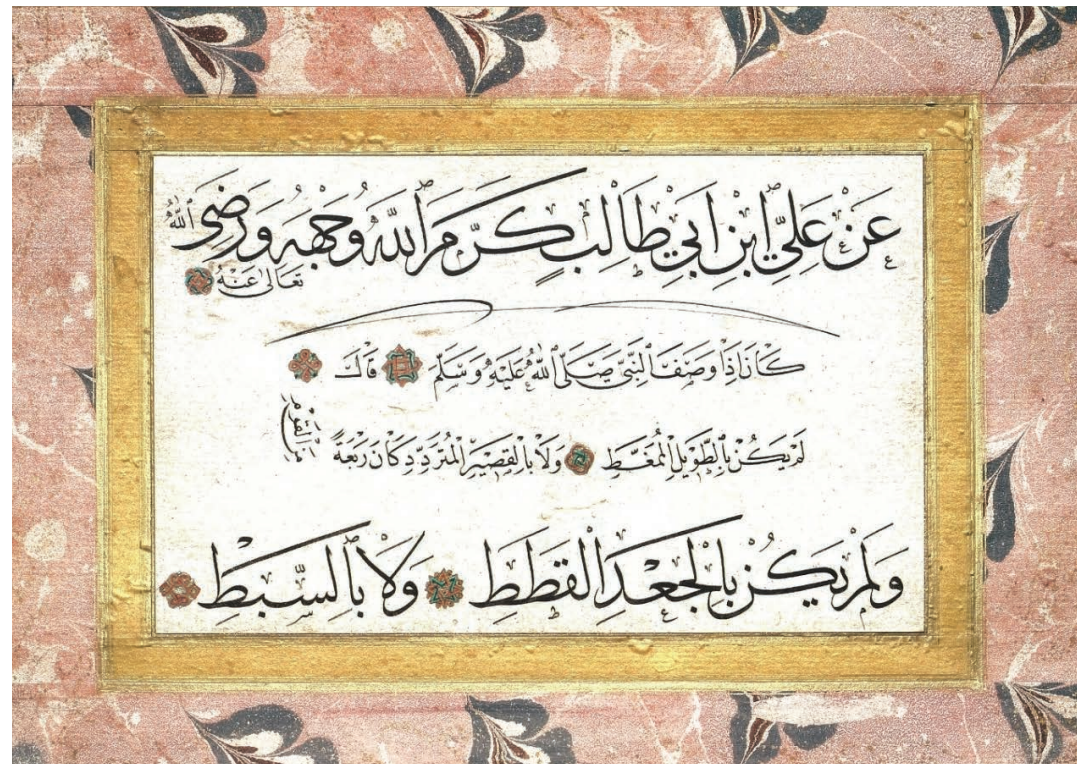

G. 9. Mehmed Şevki Efendi'nin, hilye metnini yazdığg Sülüs-Nesih kıt'ası (IRCICA, Mehmed Şevki Efendi'nin Sülüs-Nesih Hat Meşkleri, 2010) 


\section{Levhalar}

Levhalar, bir yere asılarak karşıdan bakılmak üzere hazırlanan, içinde yaşadığımız ve çeşitli amaçlar için kullandığımız mekânların duvarlarını süsleyen eserlerdir. Bu tür hat eserlerinde genellikle uzaktan okunmaya müsait Celî Sülüs, Celî Ta'lik, Celî Dîvâni gibi iri yazı formları tercih edilmiş olmakla beraber, daha ince yazılarla yazılmış olanlara da rastlanır. Çok farklı boyutlarda görülebilen levhaların ölçülerini yazılan ibarenin kompozisyonu ve etrafındaki tezyinatı belirlemektedir. Başta kısa ve özlü mesajlar içeren âyet ve hadisler olmak üzere, edebî ve hikmetli sözlerin yazıldığ bu nevi eserlerde Hz. Peygamber (a.s.) için söylenen methiyelere de yer verilmiştir.

Hz. Peygambere övgü ifade eden âyetlerden "Biz seni ancak âlemlere rahmet olarak gönderdik",33. "Şâhit olarak Allah yeter. Muhammed Allah'm elçisidir (...) "34 (G. 10); “Ey Peygamber! Biz seni hakikaten bir şahit, bir müjdeleyici ve bir uyarıcı olarak gönderdik"35; "Allah ve melekleri Peygambere çok salavat getirirler. Ey müminler! Siz de ona salavat getirin ve tam bir teslimiyetle selâm verin. ”36; “ (...) Meryem oğlu Ísa: Ey İsrâiloğulları! Ben size Allah'ın elçisiyim (...) benden sonra gelecek Ahmed adında bir peygamberi müjdeleyici olarak geldim, demişti." ${ }^{37}$ (G. 11); "Ve sen elbette yüce bir ahlak üzeresin. "38 (G. 12) mealindeki âyetleri ve benzerlerini hattatlar özellikle Celî levhalarda sıkça yazmışlardır.

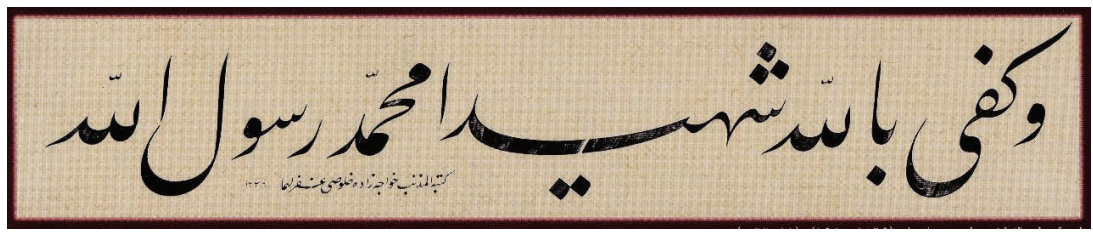

G. 10. Hulûsi Efendi'nin Celî Ta'lik levhası, Feth: 28-29 (M. Memiş fotoğraf arşivi)

33 Enbiya, 21/107.

34 Feth, 48/28-29

35 Ahzab, 33/45.

36 Ahzab, 33/56.

37 Saf, 61/6.

38 Kalem, 68/4. 


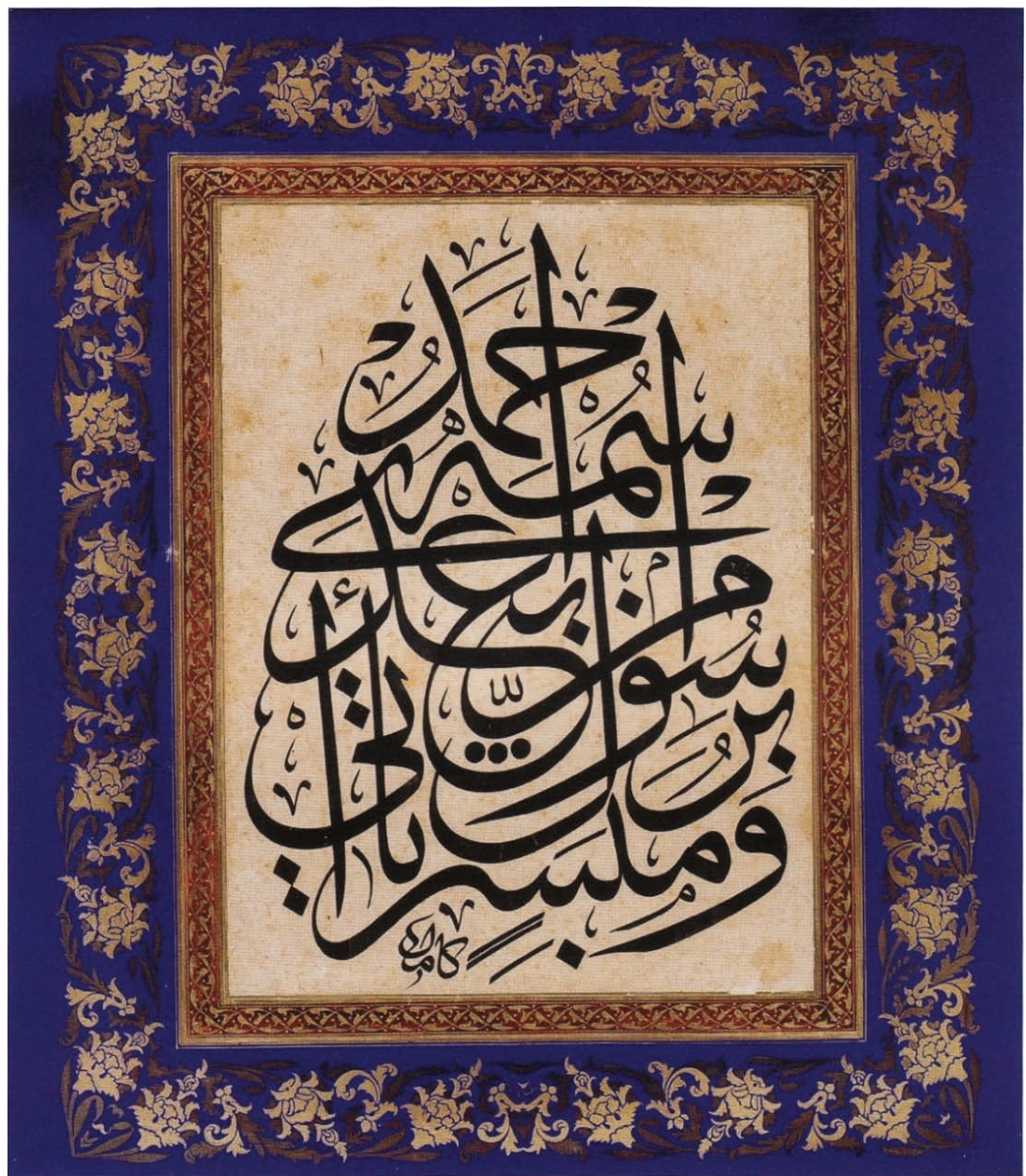

G. 11. Kâmil Akdik'in Celî Sülüs levhası, Saf: 6 (M. Memiş fotoğraf arşivi)

Hz. Peygamberin hadîs-i şerifleri ise levhalarda daha fazla yer almıştır. Müslümanlar yaşadıkları mekânları onun hikmetli sözleriyle, tavsiyeleriyle süsleyerek Hz. Muhammed (a.s.)'in sünnetini kendilerine rehber edinmişlerdir. Burada çok yaygın olarak bilinen bazı hadis metinlerinden örnekler verilmiştir (G. 13, G. 14, G. 15, G. 16). 


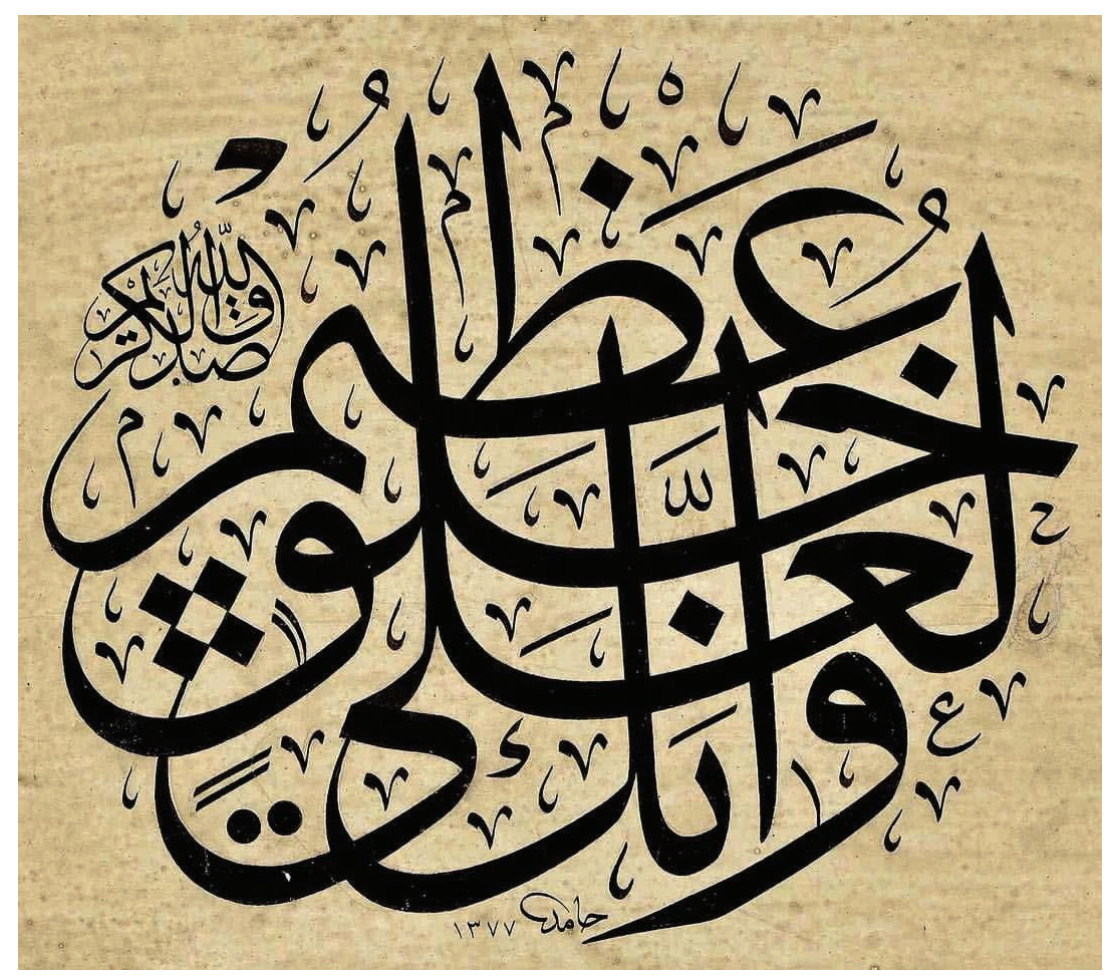

G. 12. Hamid Aytaç'ın Celî Sülüs istifi, Kalem: 4 (M. Memiş fotoğraf arşivi)

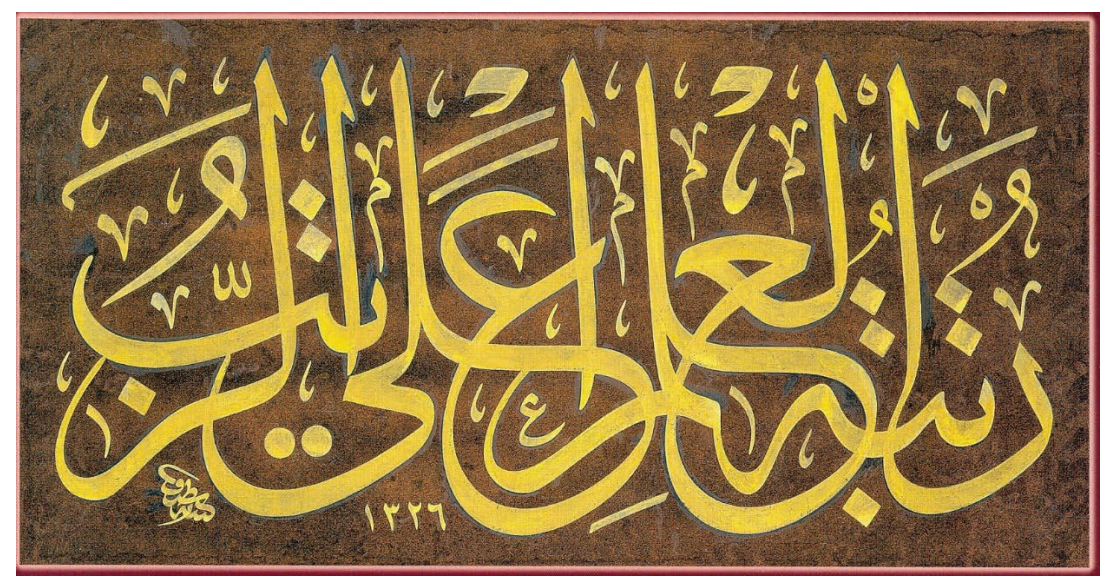

G. 13. Sami Efendi'nin Celî Sülüs levhası, "Rutbetü'l-ilmi a'le'r-ruteb (Rütbelerin en yücesi ilim rütbesidir)", (M. Memiş fotoğraf arşivi) 


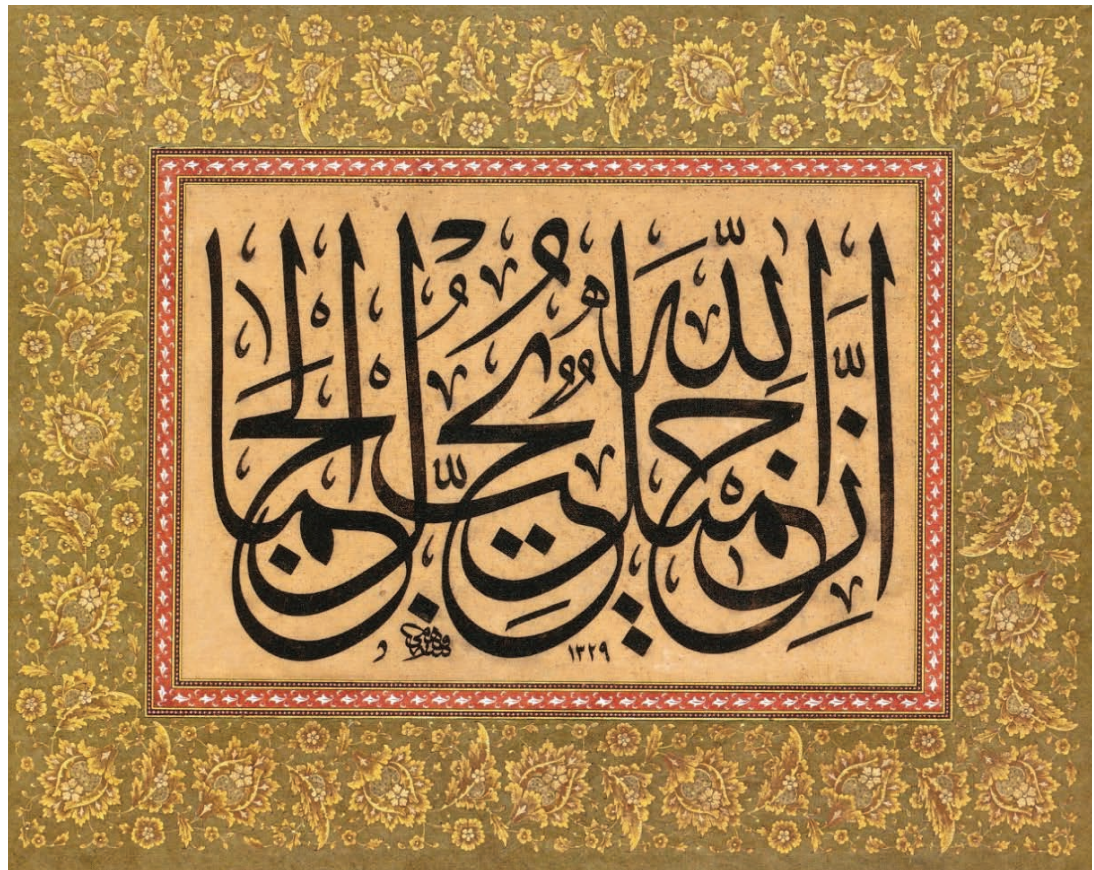

G. 14. Fehmi Efendi'in Celî Sülüs levhası, "İnnallâhe cemîlün yuhibbü'l-cemâl (Allah güzeldir güzelliği sever)”, (Derman, Harflerin Aşkı, 341)

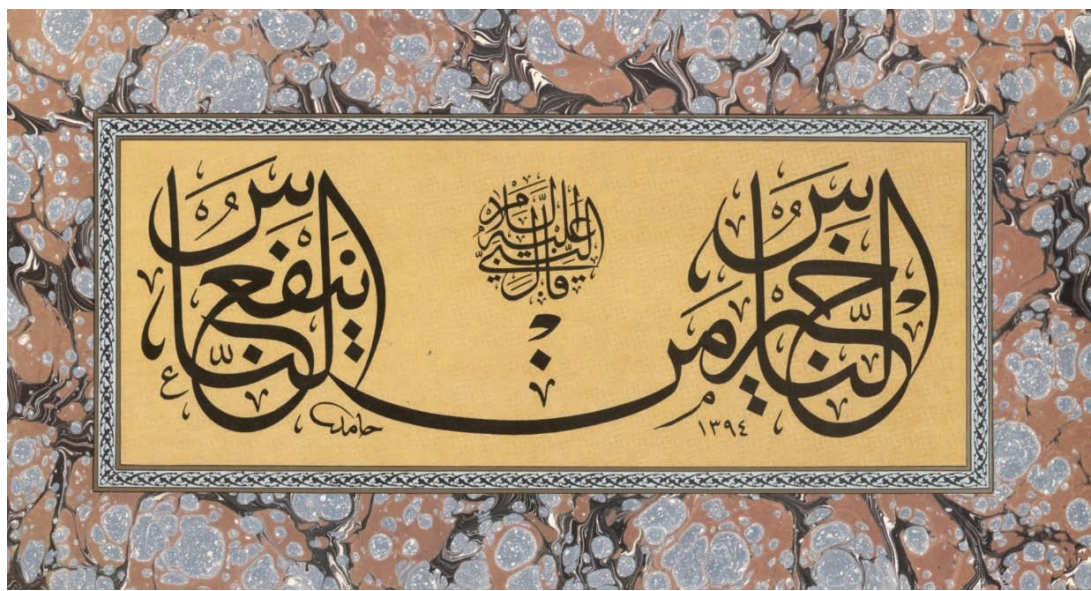

G. 15. Hâmid Aytaç'ın Celî Sülüs levhası, "Hayru'n-nâs men yenfeu'n-nâs (İnsanların en hayırlısı insanlara faydalı olandır)", (M. Memiş fotoğraf arşivi) 


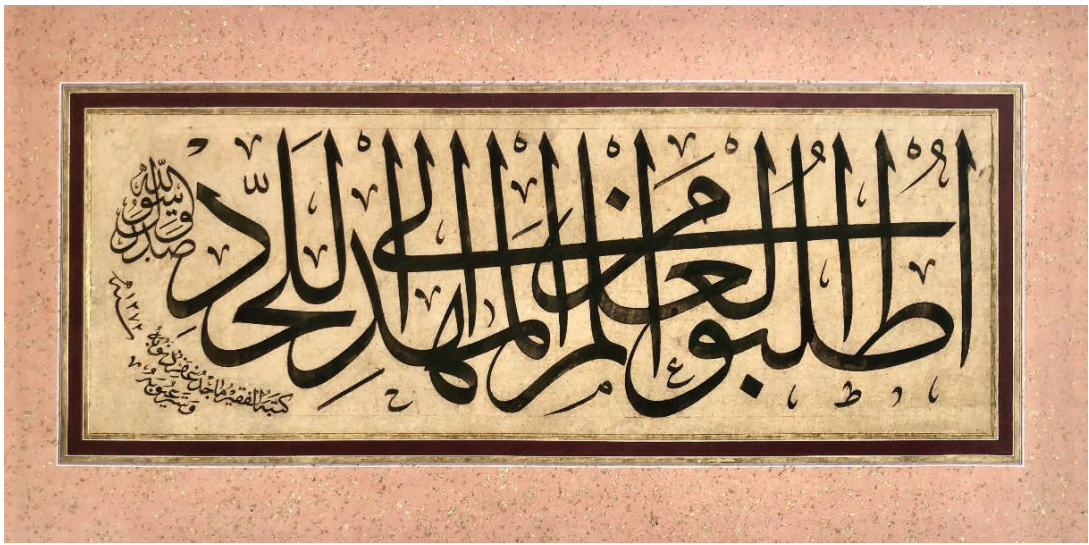

G. 16. Macid Ayral'ın Celî Sülüs levhası, "Ütlubû'l-ilme mine'l-mehdi ile'l-lahd (Beşikten mezara kadar ilim talep ediniz)”, (Derman, Türk Hat Sanatından Seçmeler, 657)

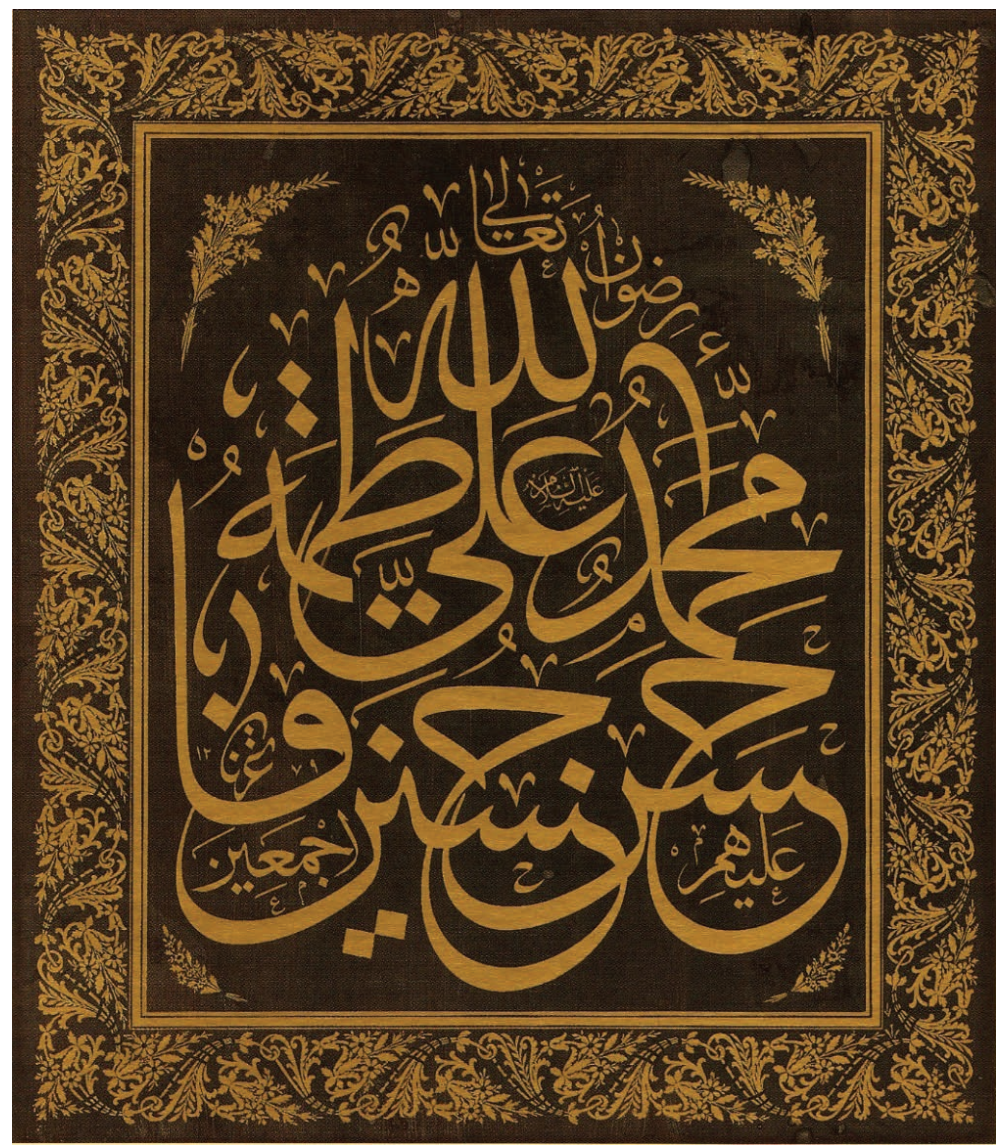

G. 17. Kazasker Mustafa İzzet' in zerendûd "Ehl-i Beyt” levhası. (M. Memiş fotoğraf arşivi) 
Celî levhaların birçoğu mürekkep yerine altın kullanılmak suretiyle Zerendûd tarzında hazırlanmıştır. Bu tür levhalarda celî yazılarıyla ünlü Sami Efendi’nin eserleri ön plandadır. Gerek zerendûd şekinde gerekse mürekkeple yazılmış olarak başta "Kelime-i Tevhid" ve "Kelime-i Şehâdet" cümleleri, "Allah" ve "Muhammed" lafizlar1, "Esmâ-i Nebî”, “Ehl-i Beyt” isimleri (G. 17) ve müminlerin Hz. Peygamber'den şefâat dileklerini içeren ifadeler (G. 18) sıklıkla görülmektedir.

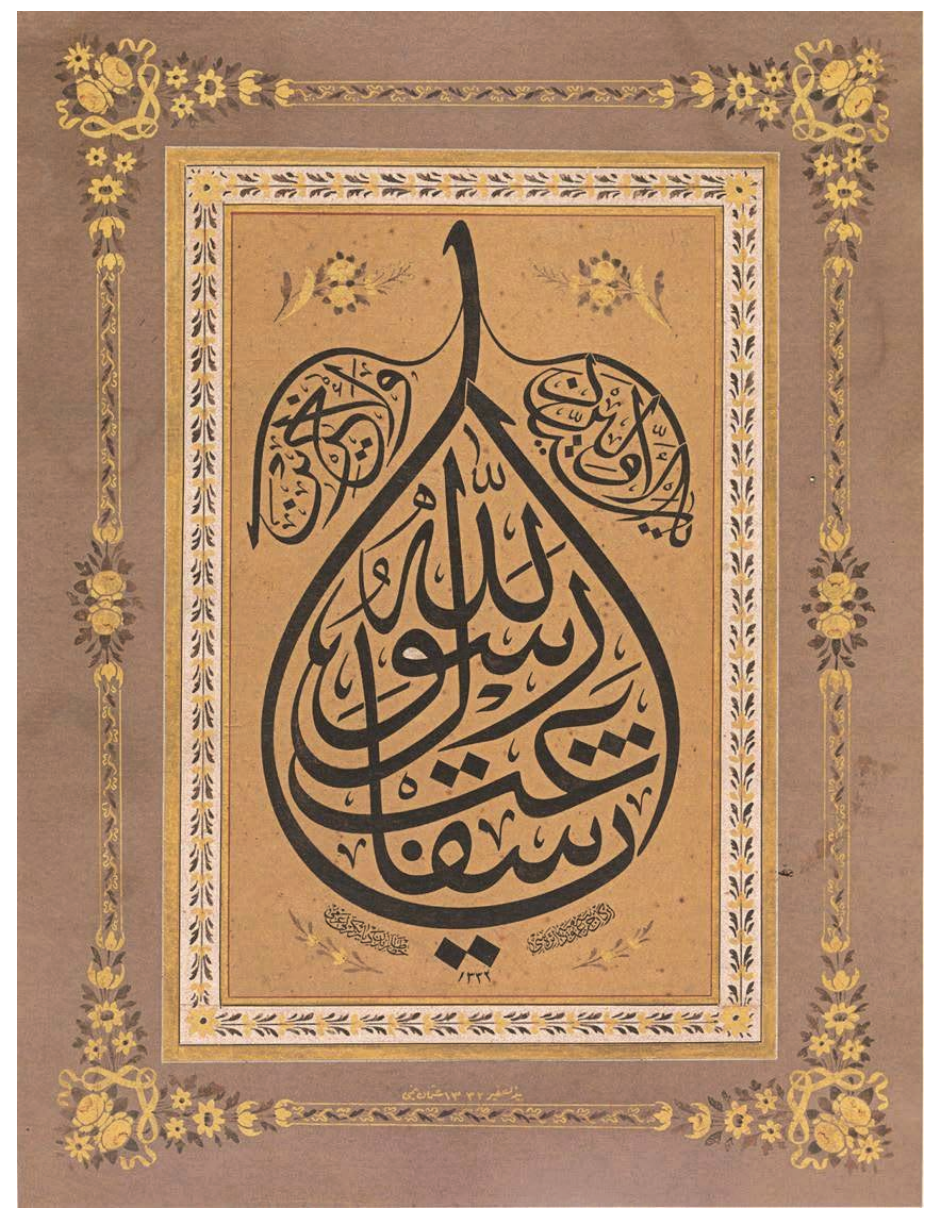

G. 18. Hâmid Aytaç'ın Celî Sülüs levhası (M. Memiş fotoğraf arşivi)

Levhalarda Resûl-i Ekrem'e övgü mahiyetindeki edebî metinler de çok yazılmıştır. Bu tarz eserlere şu örnekler verilebilir:

Mustafa Rakım'ın Celî Sülüs'le yazdığı;

"Basmasa mübârek kademin rû-yi zemîne

Pâk itmez idi kimseyi hâk ile teyemmüm”

levhasi (G. 19). 


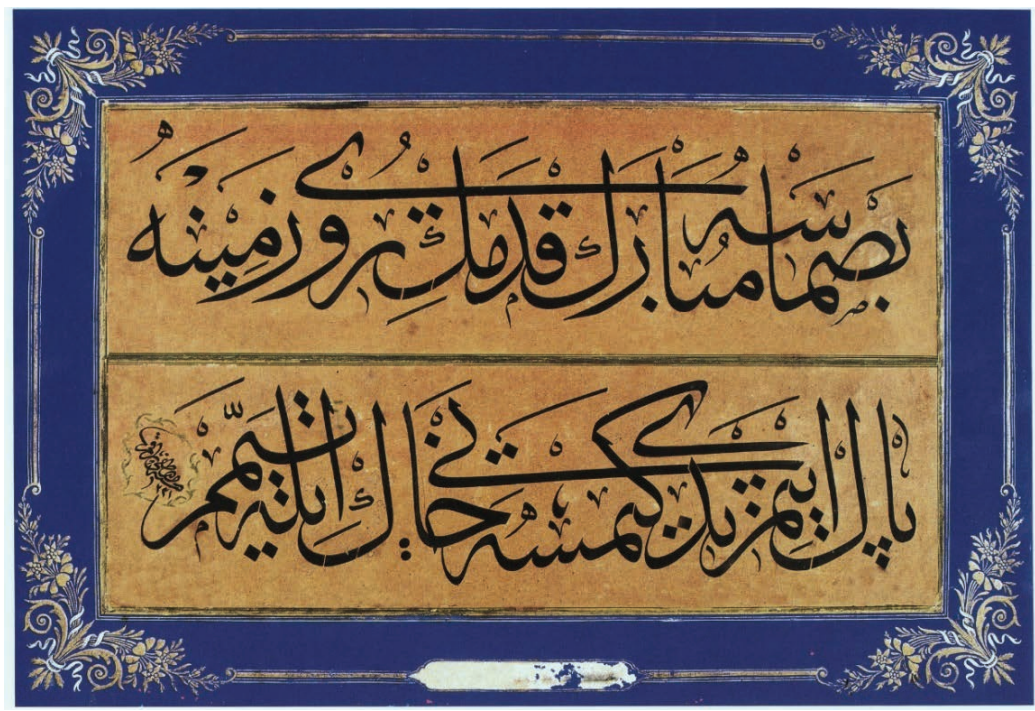

G. 19. Mustafa Râkım'ın celî sülüs levhası (Derman, Türk Hat Sanatından Seçmeler, 387)

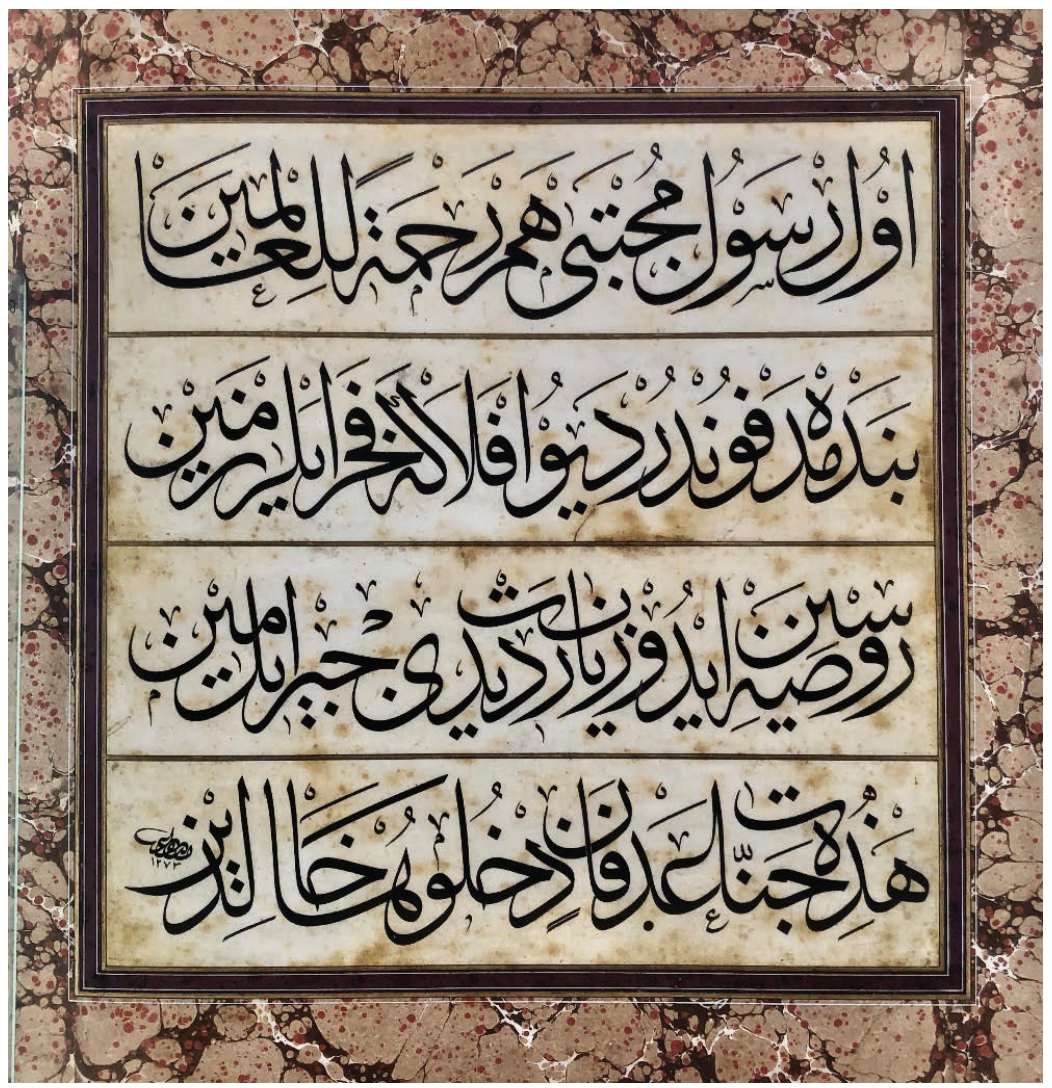

G. 20. Kazasker Mustafa İzzet'in Celî Sülüs levhası (Derman, Türk Hat Sanatından Seçmeler, 441) 
Kazasker Mustafa İzzet Efendi tarafindan yazılan;

“Ol rasûl-i müctebâ hem rahmeten li'l-âlemîn

Bende medfûndur deyu eflâke fahr eyler zemîn.

Ravzasin idüb ziyaret didi Cibrîl-i Emîn.

Hâzihî Cennât-i adnin fedhulûhâ hâlidîn"

k1t'as1 (G. 20).

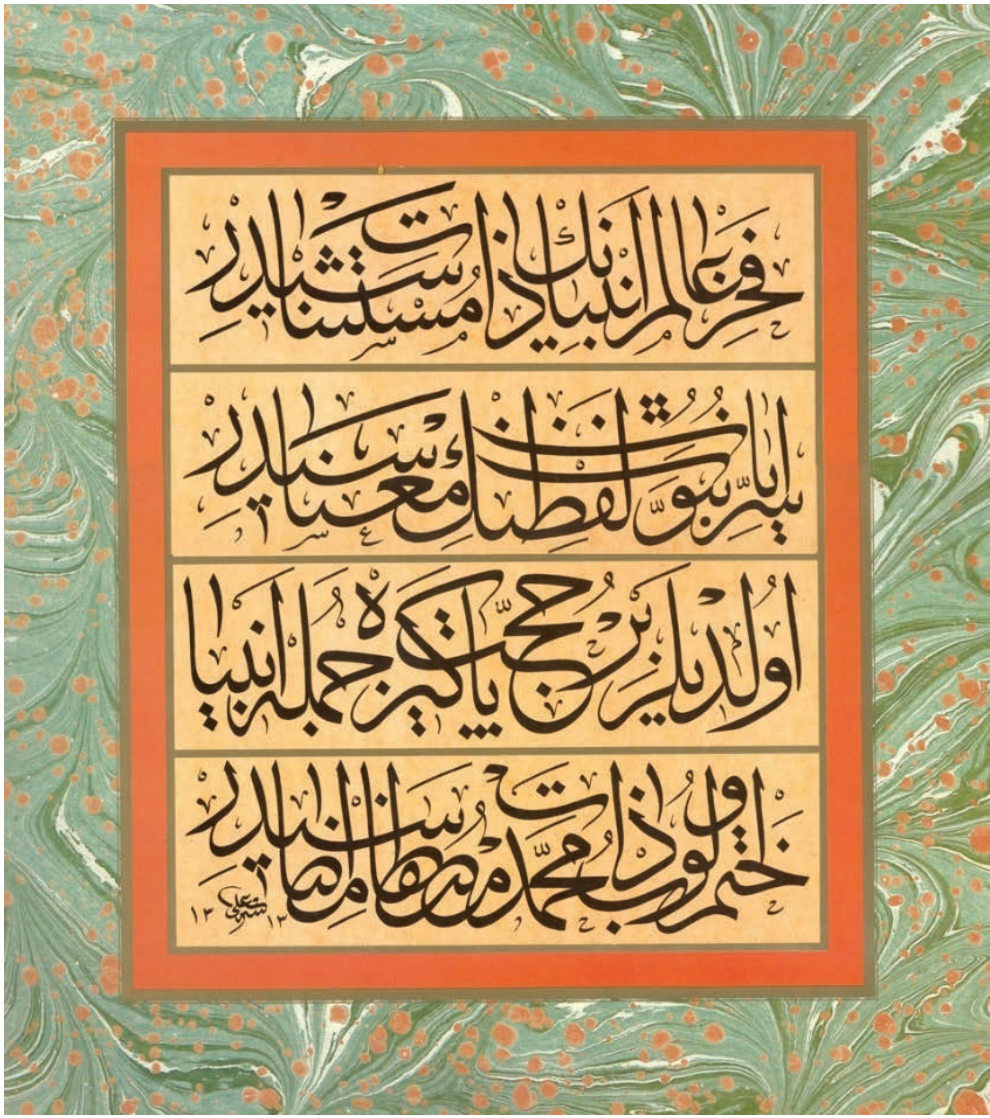

G. 21. Çırçırlı Ali Efendi’nin Celî Sülüs levhası (M. Memiş fotoğraf arşivi)

Çırçırlı Ali Efendi’nin kaleminden çıkan;

"Fahr-i âlem enbiyânın zât-ı müstesnâsıdır

Sırr-ı âyât-ı nübüvvet lafzının manasıdır

Oldular bir hüccet-i pâkize cümle enbiyâ

Hatm olup zât-ı Muhammed Mustafa imzasıdır"

yazilı levha (G. 21). 
Levhalar arasında yer alan Hilye-i Şerîfe'ler, peygamber sevgisini ifade etmeleri açısından ayrı bir öneme sahiptir. Bu yüzden onları ayrı bir başlık altında ele almak daha uygun olacaktır:

\section{a. Hilye-i Şerîfeler}

Sözlükte "Süs, ziynet, cevher, güzel sıfat, güzel yüz" manalarına gelen hilye, terim olarak Hz. Muhammed (as)'in mübarek vasıflarını, güzelliklerini anlatan manzum veya mensur edebî eserleri ${ }^{39}$ ve bu meyanda hüsn-i hatla yazılmış levhaları ifade eden bir kavramdır. Diğer peygamberleri, Hulefâ-i Râşidîn'i, bazı sahâbe ve tarikat büyüklerini vasfeden yazılı metinler anlamında da kullanılmıştır. Ancak "Hilye" denince "Na't (Naat)" kelimesinde olduğu gibi daha çok Hz. Peygamber'i tasvir eden eserler akla gelmektedir. ${ }^{40}$

İslâm inancında, putlaştırılabilecek kimselerin tasvirlerinden şiddetle kaçınılması sebebiyle, asılsız birkaç minyatür haricinde hiç kimse Resûlullah'ın resmini çizmeye gerek duymamış, buna cesaret edememiştir. Müslümanlar, Hristiyan dünyasında $\mathrm{Hz}$. İsa için olduğu gibi hayali bir resim yapmaktansa, görenlerin doğru tariflerinden yola çıkarak İslâm Peygamberi'ni öğrenip anlatmayı, böylece her Müslümanın, gönlünde beliren şekliyle peygamberini tasavvur ederek ona bağlanmasına vesile olmayı tercih etmişlerdir. ${ }^{41}$

Hz. Peygamber hayattayken onu tanıtan sözlü tasvirlere ihtiyaç duyulmuyor, görmeyi arzulayan Müslümanlar bir kez de olsa bütün imkânlarını zorlayarak Resûlullah'1 görme şerefine nâil olabiliyorlardı. Vefatından sonra Müslümanlarda derin bir peygamber hasreti başlamıştı. O hayatta iken henüz çocukluk yaşında olanlar, daha sonra doğan çocuklar ve yeni Müslüman olan yetişkinler her firsatta sahâbe nesline Hz. Peygamberin vasıfları ile ilgili sorular yöneltiyorlardı. Onu görenlerin bu sorulara cevap mahiyetindeki anlatımları zaman içinde zengin bir bilgi birikimi meydana getirmiştir. ${ }^{42}$

Sahabeler kendi bilgi ve idrakları nisbetinde Hz. Peygamberin vasıflarını tespit etmeye çalışmış ve bu konuda farklı rivâyetler ortaya çıkmıştır. Tirmizî, Kadı Iyaz gibi müellifler hadis kitaplarında "Sıfâtü'n-Nebî" ve "Fezâil" gibi başlıklar altında verilmiş olan bu rivâyetleri derleyip bir arada değerlendirerek "Şemâil" adıyla bir ilim şekline getirmişlerdir. Tirmizî’nin (ö:892) şemâil ve hilye türü eserlere kaynaklık eden eş-Şemâilü'n-Nebeviyye ve'l-Hasâisü'l-Mustafaviyye adlı eserinin birçok şerhi

39 Şemseddin Sâmi, Kâmûs-ı Türkî (İstanbul: Enderun Kitabevi, 1989), 558; Ferit Devellioğlu, OsmanlıcaTürkçe Ansiklopedik Lügat (Ankara: Aydın Kitabevi, 1992), 442.

40 M. Hüsrev Subaşı, "Hat sanatında Hz. Peygamber Sevgisiyle Doğmuş Bir Form: Hilyeler”, Kültür Coğrafyamızda Hz. Muhammed Uluslararast Sempozyum (Orta Asya, Kafkasya ve Balkanlar) 7-8 Mart 2009 Sakarya (Ankara: Diyanet İşleri Başkanlığı Yayınları, 2011), 2: 213.

41 M. Uğur Derman, "Hilye", TDV İslâm Ansiklopedisi, c. 18 (İstanbul: Türkiye Diyanet Vakfı Yayınları, 1998), 47;

Derman, "Yazı Sanatımızda Hilye-i Saadet", Ömrümün Bereketi I (İstanbul: Kubbealtı Yayınları, 2011), 191.

42 Yardım, Peygamberimizin Şemâili, 46,47. 
yapılmıştır. ${ }^{43}$ Hilye türü kaynağını şemâillerden almış olmakla beraber hilyeyi ondan farklı kılan hususiyetler söz konusudur. Şemâiller didaktik bir eser olup sadece öğretme amac1 güden ve edebî olmayan eserlerdir. Hilyeler ise sanat fikri ön plânda olan, ulvî bir gâye için yazılmış ve aynı zamanda da edebî özelliği bulunan ürünlerdir.

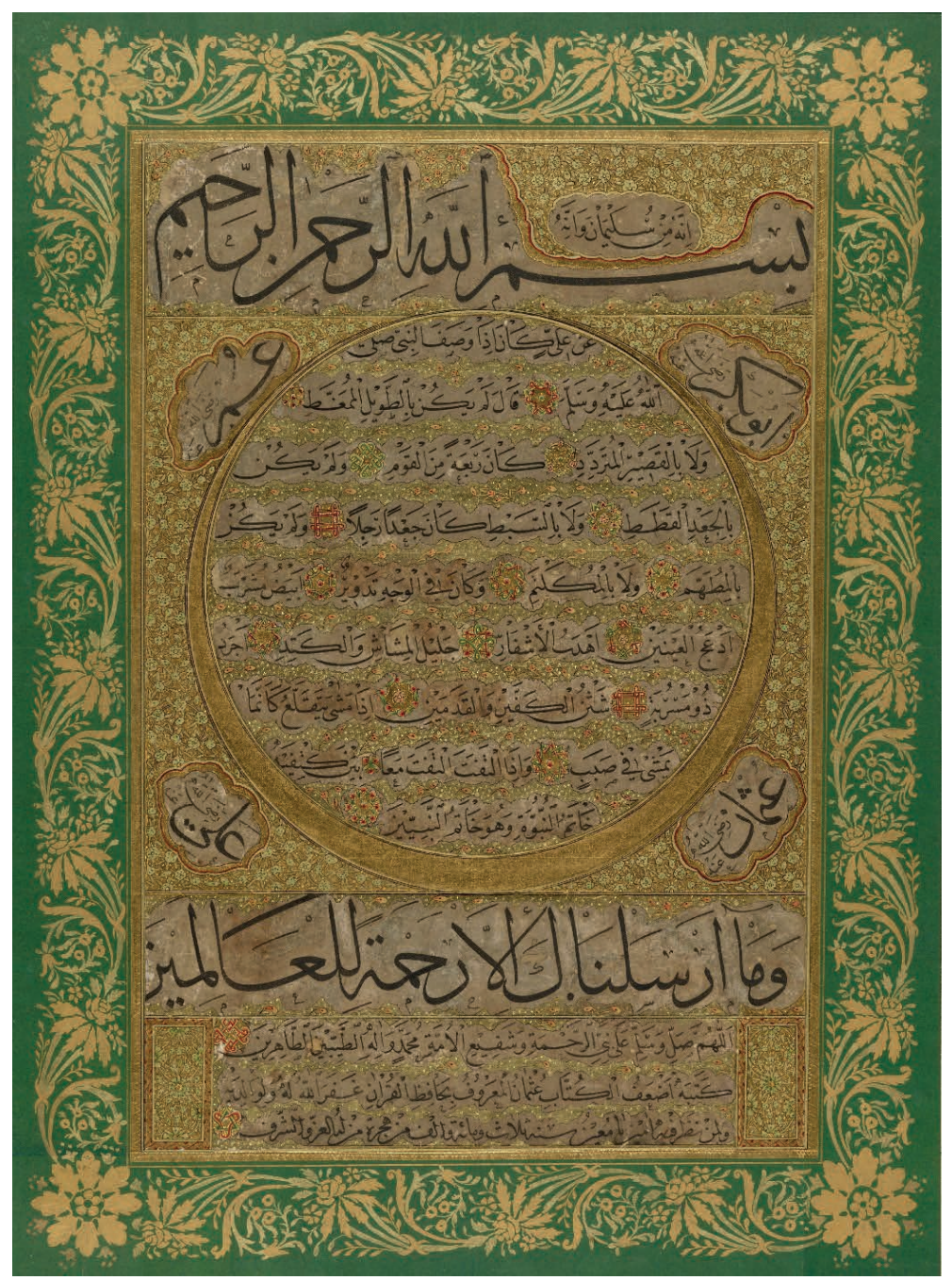

G. 22. Hâfız Osman'ın 1103/1691-1692 tarihli Sülüs-Nesih hilye-i şerîfesi (Chester Beatty Digital Collections, "Turkish Collection,” nr. T 559.4)

Türk edebiyatında hilye türünün ilk ve en önemli örneği Hâkânî Mehmet Bey'in 1007/1598-1599 tarihinde yazdığ Hilye isimli eseridir. Hilye kelimesi bu eserden sonra bilhassa Hz. Peygamber'in vücut yapısı ve sıfatları hakkında yazılan eserlerin genel adı olmuştur. Besmele hakkında bir manzumeyle başlayan eser, daha sonra $\mathrm{Hz}$.

43 Mustafa Uzun, "Hilye”, TDV İslâm Ansiklopedisi, c. 18, (İstanbul: Türkiye Diyanet Vakfi Yayınları, 1998$), 44$. 
Ali'nin hilye konusundaki rivâyetinden, hilyenin faziletlerinden söz eder. İstanbul kütüphanelerinde pek çok yazma nüshası bulunan eserde Hz. Peygamberin vücut yapısı ile ilgili özelliklerinin açıklandı̆̆ı beyitler de yer almıştır. ${ }^{44}$

Hz. Peygamber'e duyulan sevgi ve saygının neticesinde şekillenen hilyeler, bilhassa Osmanlı kültüründe önem kazanarak yaygınlaşmış, taşıdıkları kudsî mânâ sebebiyle hilyeler etrafında birtakım inançlar meydana gelmiştir. ${ }^{45}$ Dînî bir dayanağı tespit edilememiş olmakla beraber içinde hilye bulunan evin felâkete uğramayacağına, üzerinde hilye bulunan kimsenin musibetlerden korunacağına, ${ }^{46}$ Peygamberi rüyâsında göreceğine, hilyeyi ezberleyenlerin dünya ve âhirette çeşitli nimetlere ereceğine ${ }^{47}$ hilye bulunan evde huzur, mutluluk ve bereket olacağına ${ }^{48}$ dair inanışlar Müslümanların hilyeye teveccühü konusunda teşvik edici bir rol oynamıştır.

Bir hürmet ifadesi olarak göğüs cebinde taşınmak üzere, küçük çapta yazılagelen hilye metninin Osmanlı hat sanatında görülebilen en eski örneği Şeyh Hamdullah’a (1429-1520) aittir. Bir duâ mecmuasının sonunda yer alan bu örnekte, Nesih hattıyla yazılan asıl metnin satır aralarında daha ince bir Nesih ile Türkçe meâli de verilmiştir. ${ }^{49}$ Hilyenin müstakil levhalar hâlinde yazılıp süslenmesi ise yalnız Osmanlı Türkleri’ne has olup başka İslâm ülkelerinde böyle bir uygulama görülmez. Kaynaklarda açıkça yazılmamakla beraber levha şeklindeki hilyenin ilk kez Hattat Hâfız Osman (ö. 1110/1698) tarafindan yazıldığı kabul edilmektedir (G. 22). ${ }^{50}$ Bu konudaki sözlü rivâyetler, benzeri bir levhaya daha önce tesadüf edilmemesi; Hâfız Osman'ın ise farklı hilye metinlerini araştırıp bulmak ve bunları yazmak konusundaki gayretlerinin bilinmesi, bu kanaatin doğruluğunu desteklemektedir. ${ }^{51}$

44 Uzun, "Hâkâni Mehmed Bey", 167.

45 Muhittin Serin, "Hilye-i Şerif”, Hilye-i Şerîfe - Hz. Muhammed'in Özellikleri, Ed. Faruk Taşkale ve Hüseyin Gündüz (İstanbul: Antik A.Ş. 2011), 93.

46 Uzun, "Hilye", 44.

47 Acar, Türk Hat Sanatı, 153.

48 Yardım, Peygamberimizin Şemâili, 61.

49 M. Uğur Derman, "Hat Sanatımızda Hilye-i Nebevî’nin Doğuşu”, Hilye-i Şerîfe - Hz. Muhammed'in Özellikleri, Ed. Faruk Taşkale ve Hüseyin Gündüz (İstanbul: Antik A.Ş., 2011), 23.

50 M. Hüsrev Subaşı, Süleymaniye Kütüphanesi no: 578 de kayıtlı, sonradan tezhiblenmiş, imzasız bir hilyenin yazı karakteri itibariyle XVII. Yüzyıldan öncesine ait izler taşıdığını ve Yakut tarzı bir nesih ile yazıldığını, dolayısıyla bu hilyenin daha eski olabileceğini ayrıca Hafız Osman imzalı ilk örneklerine bakılarak bilinen şekliyle hilye tasarımının Hafız öncesinde bir süreçten geçerek şekillenmiş olabileceğini ifade etmektedir. Bkz. Subaşı, "Hat Sanatında Hz. Peygamber Sevgisiyle Doğmuş Bir Form: Hilyeler", 216.

51 Derman, "Hilye", 47-50. 


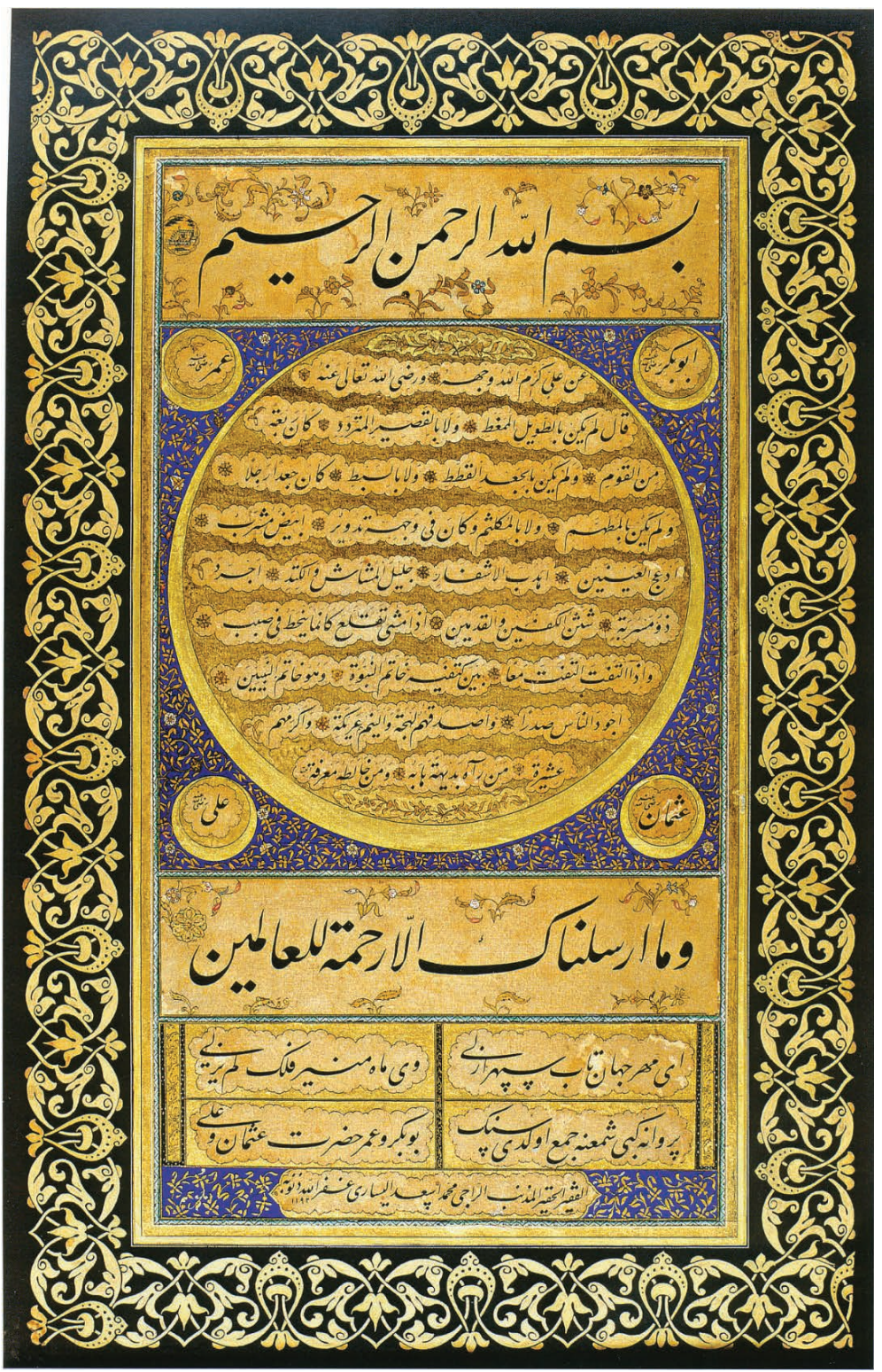

G. 23. Mehmed Esat Yesari'nin Ta'lik hilyesi (Hilye-i Şerîfe - Hz. Muhammed'in Özellikleri, 62)

Klâsik formdaki hilye levhalarında şu bölümler bulunur:

1. Baş makam: En üstte yer alan bu kısma Besmele yazılır.

2. Göbek: Besmelenin altındaki bu alanda Hz. Peygamber'i anlatan rivayetler, genellikle de Hz. Ali tarafından yapılan tavsif metni bulunur. Burası çoğunlukla dairesel, bazen de oval veya kare formunda düzenlenmiştir. 
3. Çehâr Yâr (Hulefâ-i Râşidîn) isimleri: Göbek kısmını çevreleyen kare veya dikdörtgenin köşelerinde oluşan üçgen alanlar içine genellikle dairevî, bazen de oval olarak Hulefâ-i Râşidîn (Ebû Bekir, Ömer, Osman, Ali r.a.) isimleri yazılır.

4. Âyet (kuşak): Göbek kısmının hemen altında yer alır ve buraya Hz. Peygamber'le ilgili bir âyet yazılır. Genellikle "Biz seni ancak âlemlere rahmet olarak gönderdik." ${ }^{52}$ meâlindeki âyet tercih edilmiştir.

5. Etek: Büyük bir bölümü göbek alanında yazılmış olan hilye metninin kalan kısmı, âyetin hemen altındaki bu son bölüme yazılır. Devamında Hz. Peygamber (a.s.)'e salât-u selâm cümleleri, hattatın imzası ve yazılış tarihiyle biter.

Besmele, âyet ve Çehâr Yâr isimlerinin Sülüs, metin kısmının Nesih'le yazıldığı klâsik tarz hilyelerde bazen besmelenin Muhakkak hattı ile yazıldığı da görülür. Bilâhare hilyelerin Ta'lik hattı ve onun incesi (Hurde Ta'lik) ile (G. 23), tamamı Sülüs veya tamamı Kûfî ile yazılmış örnekleri yanında, bilinen hilye formu dışında farklı şekillerde denemeleri de yapılmıştır (G. 24). Hz. Ali'den rivâyet edilen hilye metninin Türkçe anlamı şöyledir:

“Hz. Ali (r.a.) Hz. Peygamberi (a.s.) vasfettiği zaman şöyle buyurdu: 'Hz. Peygamber'in boyu ne çok kısa, ne de çok uzundu. Kavminin orta boylusu idi. Saçları ne kıvırcık kısa, ne de düz uzun idi, kıvırcıkla düz arası idi. Dolgun etli değildi. Çehresi de çok yuvarlak değildi. Değirmi yüzlü, duru beyaz tenli, iri ve siyah gözlü, uzun kirpikliydi. Iri kemikli ve geniş omuzluydu. Göğsü, ortadan karnına kadar kılsızdl. İki avucu ve tabanları dolgundu. Yürüdüğü zaman, sanki yokuş aşağı iner gibi rahatlıkla ilerlerdi. Sağına ve soluna baktığında, bütün vücuduyla dönerdi. İki omuzu arasında 'nübüvvet mührü' vardl ve bu onun sonuncu peygamber oluşunun nişânesi idi. O insanların en cömert gönüllüsü, en doğru sözlüsü, en yumuşak huylusu ve en arkadaş canlısı idi. Kendilerini ansızın görenler, heybeti karşısında sarsıntı geçirirler; fakat üstün vasıflarını bilerek sohbetinde bulunanlar ise, onu çok severlerdi. O'nun üstünlüklerini ve güzelliklerini tanıtmaya çalışan kimse: 'Ben, ne ondan önce ve ne de ondan sonra, onun gibi birisini görmedim'demekten kendini alamazdı. Allah'ın salât ve selâmı onun üzerine olsun. "53

\section{Enbiyâ, 21/107.}

53 Hilye levhalarında en çok yazılan Hz. Ali rivayetinin Türkçe anlamı için bkz. M. Uğur Derman, "Hat Sanatında Osmanlı Devri”, İslâm Kültür Mirâsında Hat Sanatı (İstanbul: IRCICA, 1992), 40; Yardım, Peygamberimizin Şemâili, 65; M. Hüsrev Subaşı, "Yaygınlaşmış Şekil ve Muhtevası İle Hilye-i Şerîfe ve Bölümleri”, Hilye-i Şerîfe - Hz. Muhammed'in Özellikleri, Ed. Faruk Taşkale ve Hüseyin Gündüz, (İstanbul: Antik A.Ş., 2011), 43-45; Serin, "Hilye-i Şerif”, 93; İskender Pala, "Gülü Tarife Ne Hacet, Ne Çiçektir Biliriz”, Hilye- $i$ Şerîfe - Hz. Muhammed'in Özellikleri (İstanbul: Antik A.Ş., 2011), 51. 


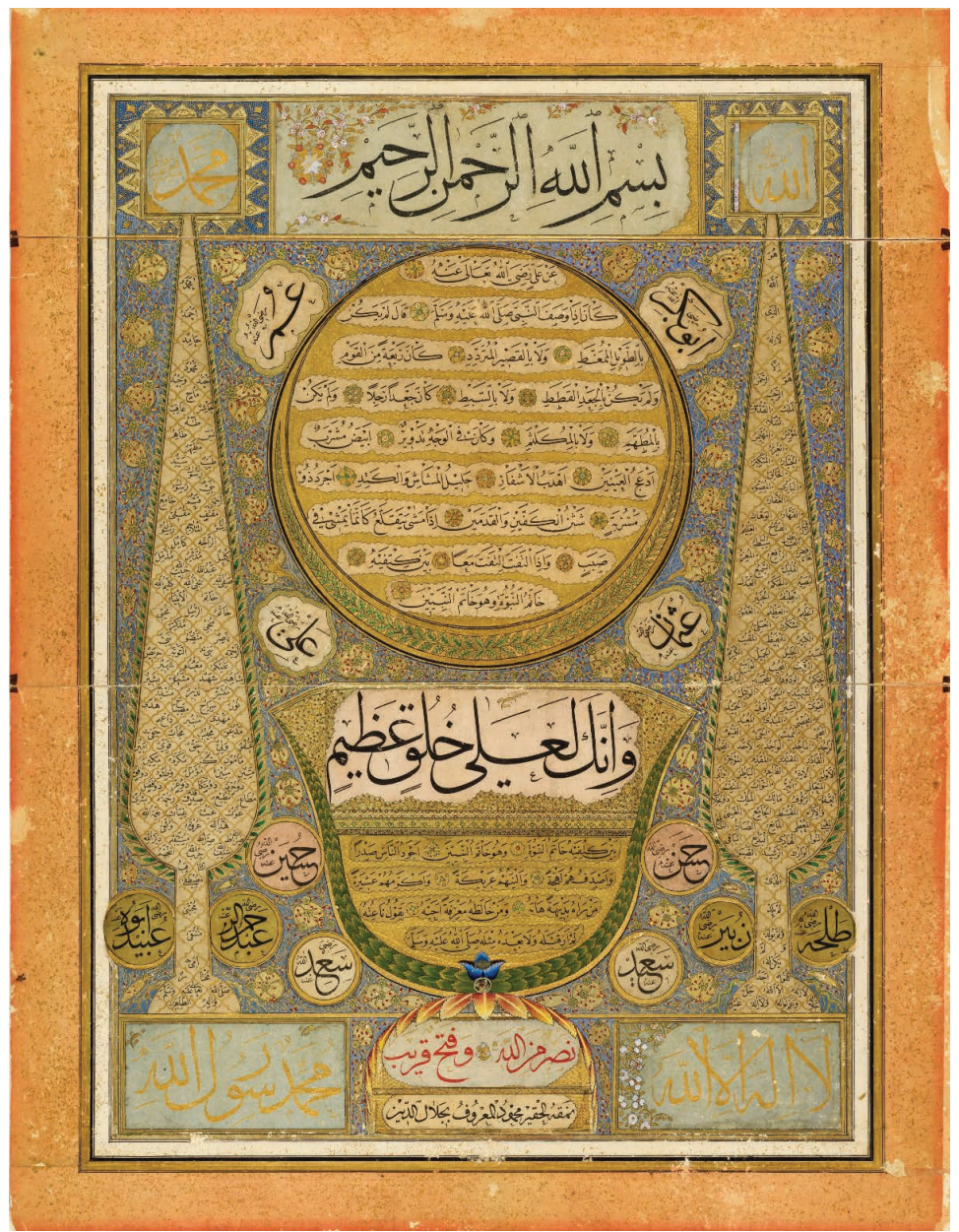

G. 24. Mahmud Celâleddin'in Esmâü'l-Hüsnâ ve Esmâü'n-Nebi ilâveli hilye-i şerîfesi (Chester Beatty Digital Collections, "Turkish Collection," nr. T 559.5)

Hat sanatının bütün incelikleriyle usta hattatlar tarafindan yazılan hilyeler, yine usta müzehhibler tarafından mahiyetine yaraşır şekilde tezhiblenerek daha da mükemmel hâle getirilmiştir. Hilye metninin yer aldığı dairevî göbek kısmının, uçları baş makama doğru bakan bir hilalle çevrelenmesi yaygın bir uygulamadır. Hz. Peygamber bu âlemi nuruyla aydınlattığ 1 için güneşe ve aya benzetilir. Göbek kısmında güneş, onu çevreleyen dış kısmında da hilal şekli oluşturulmuştur. Etrafındaki Hulefâ-i Râşidîn isimleri ile de "Ashabım yıldızlar gibidirler, hangisine uysanız doğru yolu bulursunuz." meâlindeki hadîs-i şerife telmihte bulunulduğu kabul edilir. ${ }^{54}$ Hilyelerde süslemenin en yoğun olduğu yer, genellikle kare veya hafif dikdörtgen şeklindeki bu bölümdür. Metnin devamının yazıldığı etek kısmının iki yanında kalan ve tezyîni motiflerle bezenen dikdörtgen alanlara koltuk adı verilir. 
Teberrüken "Hilye-i Saadet", "Hilye-i Nebevî" veya "Hilye-i Şerîfe" terkipleriyle de isimlendirilen bu eserler, eskiden olduğu gibi zamanımızda da sanatseverlerin ilgi odağı olmaya devam etmekte, günümüz hattatları tarafından gerek klasikleşen şekliyle ve gerekse yeni ve farklı denemeleriyle çok güzel örnekleri üretilmektedir.

\section{Sonuç}

İslâm'ın gelişiyle birlikte, yazının ilahi vahyin tespit ve muhafazasında üstlendiği rol, aynı zamanda ona bir kutsiyet atfedilmesine de vesile olmuştur. Bu yüzden Müslümanların sanat uğraşıları içinde hüsn-i hattın önemli ve özel bir yeri bulunmaktadır. Daha çok Mushaf kitabeti üzerinde seyreden uzun bir gelişme sürecinden sonra, bu sanatın Osmanlı döneminde tarihinin zirvesine ulaştığı görülür. Yazma kitaplarda, levhalarda, kitabelerde ve mimarî yapılar üzerinde günümüze ulaşan göz alıcı eserler, Osmanlı Türklerinin bu alandaki başarısını teyit eder niteliktedir.

Bu nadide hat eserleri bir taraftan sanat yönüyle gözlere hitap ederken, ele aldığ 1 konular ve işlediği metinlerle de zihinlere ve gönüllere müessir mesajlar iletmektedir. Yazının kullanıldığı hemen her alanda eser veren hattatlar, asırlar boyu başta Kur'ân-1 Kerîm'ler, ayetler olmak üzere, en fazla Hz. Muhammed (a.s.)'in örnek şahsiyeti ve hadisleri etrafında sınırsız güzel eserler ortaya koymuşlar ve bu vesileyle halkın dinî, ahlakî, sosyal ve içtimai alanlardaki eğitimine de katkı sağlamışlardır.

Hakem Değerlendirmesi: Dış bağımsız.

Çıkar Çatışması: Yazar çıkar çatışması bildirmemiştir.

Finansal Destek: Yazar bu çalışma için finansal destek almadığını beyan etmiştir.

Peer-review: Externally peer-reviewed.

Conflict of Interest: The author has no conflict of interest to declare.

Grant Support: The author declared that this study has received no financial support.

\section{Kaynakça / References}

Acar, M. Şinasi. Türk Hat Sanatı. İstanbul: Antik A.Ş. Kültür Yayınları, 1999.

Altıkulaç, Tayyar. Hz. Osman'a Nisbet edilen Mushaf-ı Şerîf (Türk ve İslam Eserleri Nüshası). 1 cilt. İstanbul: Türkiye Diyanet Vakfı İslam Araştırmaları Merkezi, 2007.

Aydın, Arafat. "Hattat Hasan Rızâ Efendi’nin Buhârî-i Şerîf Nüshası.” Hattat Hasan Rızâ Hattı Buhârî-i Şerîf. İstanbul: Diyanet İşleri Başkanlığı Yayınları, 2017, XXXIII-XXXIX.

Berk, Süleyman. Hattat Mustafa Râkım Efendi. İstanbul: Kaynak Yayınları, 2003.

1400. Yılında Kur'ân-ı Kerîm. İstanbul: Antik A.Ş. Kültür Yayınları, 2010.

Buhârî-i Şerîf. İstanbul, Topkapı Sarayı Müzesi Kütüphanesi, Hırka-i Saâdet, 39, İstinsah tarihi evâsit-1 Rebîu'l-Âhir 1331 (Mart 1913).

Chester Beatty Digital Collections. "Turkish Collection.” erişim 4 Mayıs 2020. https://viewer.cbl. ie/viewer/object/T_559_4/1/LOG_0000/ 
Çetin, Nihad M. “İslâm Hat Sanatının Doğuşu ve Gelişimi.” İslâm Kültür Mirasında Hat Sanatı, İstanbul: IRCICA, 1992.

Çetin, Nihad M. ve M. Uğur Derman. İslâm Kültür Mirasında Hat Sanatı. İstanbul: IRCICA, 1992.

Derman, M. Uğur. "Hat Sanatında Osmanlı Devri”. İslâm Kültür Mirasında Hat Sanatı. İstanbul: IRCICA, 1992.

Derman, M. Uğur. "Hilye”, TDV İslâm Ansiklopedisi. 18. İstanbul: Türkiye Diyanet Vakfı Yayınları, 1998, 47-51.

Derman, M. Uğur. Sakıp Sabancı Müzesi Hat Koleksiyonundan Seçmeler. İstanbul: Akbank Yayınlar1, 2002.

Derman, M. Uğur. "Murakkaa". TDV İslâm Ansiklopedisi. 31. İstanbul: Türkiye Diyanet Vakfı Yayınları, 2006, 204-205.

Derman, M. Uğur. Doksandokuz İstanbul Mushafi. İstanbul: Türk Petrol Vakfi, 2010.

Derman, M. Uğur. "Yazı Sanatımızda Hilye-i Saadet”, Ömrümün Bereketi: I. İstanbul: Kubbealtı Yayınları, 2011.

Derman, M. Uğur. "Hat Sanatımızda Hilye-i Nebevî'nin Doğuşu”. Hilye-i Şerîfe - Hz. Muhammed'in Özellikleri. Ed. Faruk Taşkale ve Hüseyin Gündüz. İstanbul: Antik A.Ş. Kültür Yayınları, 2011, 23-30.

Derman, M. Uğur. Harflerin Aşkl, Kerem Klyak ve Mustafa Balcı Koleksiyonlarından. İstanbul: Korpus Yayınları, 2014.

Derman, M. Uğur. Türk Hat Sanatından Seçmeler. Ankara: Atatürk Kültür Merkezi, 2017.

Devellioğlu, Ferit. Osmanlıca-Türkçe Ansiklopedik Lügat. Ankara: Aydın Kitabevi, 1992.

El-Begavî. Mesâbihu’s-Sünne. Topkapı Sarayı Müzesi Kütüphanesi, III. Ahmed, nr. 278.

İlter, Elif. "Hattat Hasan Rıza Efendi’nin Hayatı ve Eserleri.” Yüksek Lisans Tezi, Sakarya Üniversitesi, 2017.

Kazan, Hilal. Dünden Bugüne Hanım Hattatlar. İstanbul: İBB Kültür A.Ş., 2010.

Memiş, Mehmet. "Hat Sanatına Terminolojik Bir Yaklaşım”, XX. Uluslararası Ortaçağ ve Türk Dönemi Kazıları ve Sanat Tarihi Araştırmaları Sempozyumu Bildirileri, 2. cilt. Sakarya: Sakarya Üniversitesi Yayınları, 2017, 554-565.

Muslihıddîn-i Lârî. Şerh-i Şemâil-i Tirmizî. Topkapı Sarayı Müzesi Kütüphanesi, III. Ahmed, nr. 4581.

Pala, İskender. “Gülü Tarife Ne Hacet, Ne Çiçektir Biliriz.” Hilye-i Şerîfe - Hz. Muhammed'in Özellikleri. Ed. Faruk Taşkale ve Hüseyin Gündüz. İstanbul: Antik A.Ş. Kültür Yayınları, 2011, 49-55.

Sakıp Sabancı Müzesi Dijital Koleksiyonları ve Arşivleri. "Kitap Sanatları ve Hat Koleksiyonu." Erişim 10 Mayıs 2020. https://digitalssm.org/digital/collection/Kitapvehat/id/182527/rec/2

Serin, Muhittin. Şeyh Hamdullah. İstanbul: Kubbealtı Yayınları, 1992.

Serin, Muhittin. "Muhammed." TDV İslâm Ansiklopedisi. 30. İstanbul: Türkiye Diyanet Vakfi Yay1nlar1, 2005, 479-481.

Serin, Muhittin. Kemal Batanay. İstanbul: Kubbealtı Yayınları, 2006.

Serin, Muhittin. "Mushaf'. TDV İslâm Ansiklopedisi. 31. İstanbul: Türkiye Diyanet Vakfı Yayınları, 2006, 248-254.

Serin, Muhittin. Hat Sanatı ve Meşhur Hattatlar. İstanbul: Kubbealtı Yayınları, 1999. 
Serin, Muhittin. "Hilye-i Şerif." Hilye-i Şerîfe - Hz. Muhammed'in Özellikleri. Ed. Faruk Taşkale ve Hüseyin Gündüz. İstanbul: Antik A.Ş. Kültür Yayınları, 2011, 91-95.

Subaşı, M. Hüsrev. "Hat sanatında Hz. Peygamber Sevgisiyle Doğmuş Bir Form: Hilyeler.” Kültür Coğrafyamızda Hz. Muhammed Uluslararası Sempozyumu 7-8 Mart 2009 Sakarya. 2. cilt. Ankara: Diyanet İşleri Başkanlığı Yayınları, 2011, 211-264.

Subaşı, M. Hüsrev. "Yaygınlaşmış Şekil ve Muhtevası İle Hilye-i Şerîfe ve Bölümleri”, Hilye-i Şerîfe - Hz. Muhammed'in Özellikleri. Ed. Faruk Taşkale, Hüseyin Gündüz. İstanbul: Antik A.Ş. Kültür Yayınları, 2011. 39-47.

Şemseddin Sâmi. Kâmûs-ı Türkî. İstanbul: Enderun Kitabevi, 1989.

Uludağ, Süleyman. "Delâilü'l-hayrât.” TDV İslâm Ansiklopedisi. 9. İstanbul: Türkiye Diyanet Vakfı Yayınları, 1994, 113-114.

Uzun, Mustafa. "Hâkani Mehmed Bey." TDV İslâm Ansiklopedisi. 15. İstanbul: Türkiye Diyanet Vakf1 Yayınları, 1997, 166-168.

Uzun, Mustafa. "Hilye”, TDV İslâm Ansiklopedisi. 18. İstanbul: Türkiye Diyanet Vakfı Yayınları, 1998, 44-47.

Yardım, Ali. Peygamberimizin Şemâili. İstanbul: Damla Yayınevi, 1997.

Yavuz, Yusuf Şevki. "Delâilü'n-Nübüvve.” TDV İslâm Ansiklopedisi. 9. İstanbul: Türkiye Diyanet Vakfi Yayınları, 1994, 115-117.

Yılmaz, Abdülkadir. Türk Kitap Sanatlarl Tabir ve Istılahlarl. İstanbul: Damla Yayınevi, 2004. 